

\section{Information and Empire}

Mechanisms of Communication in Russia, 1600-1850

Edited by Simon Franklin and Katherine Bowers 


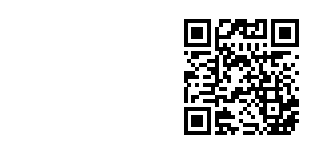

https://www.openbookpublishers.com

(c) 2017 Simon Franklin and Katherine Bowers.

Copyright of each chapter is maintained by the author.

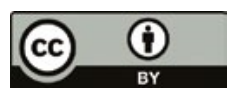

This work is licenced under a Creative Commons Attribution 4.0 International license (CC BY 4.0). This license allows you to share, copy, distribute and transmit the work; to adapt the work and to make commercial use of the work providing attribution is made to the authors (but not in any way that suggests that they endorse you or your use of the work). Attribution should include the following information:

Simon Franklin and Katherine Bowers, Information and Empire: Mechanisms of Communication in Russia, 1600-1850. Cambridge, UK: Open Book Publishers, 2017, http:// dx.doi.org/10.11647/OBP.0122

In order to access detailed and updated information on the license, please visit https:// www.openbookpublishers.com/product/636\#copyright

Further details about CC BY licenses are available at http://creativecommons.org/licenses/ by/4.0/

All external links were active at the time of publication unless otherwise stated and have been archived via the Internet Archive Wayback Machine at https://archive.org/web

Digital material and resources associated with this volume are available at https://www. openbookpublishers.com/product/636\#resources

Every effort has been made to identify and contact copyright holders and any omission or error will be corrected if notification is made to the publisher.

ISBN Paperback: 978-1-78374-373-5

ISBN Hardback: 978-1-78374-374-2

ISBN Digital (PDF): 978-1-78374-375-9

ISBN Digital ebook (epub): 978-1-78374-376-6

ISBN Digital ebook (mobi): 978-1-78374-377-3

DOI: $10.11647 / \mathrm{OBP} .0122$

Cover image: Top: Clement Cruttwell, Map of the Russian Empire, in Atlas to Cruttwell's Gazetteer, 1799, image by Geographicus Fine Antique Maps (https://commons.wikimedia. org/wiki/File:1799_Clement_Cruttwell_Map_of_Russian_Empire_-_Geographicus_-_Russiacruttwell-1799.jpg). Bottom: image from the first Italian edition of Sigismund von Herberstein's description of Muscovy (Venice, 1550), private collection.

Cover design by Katherine Bowers and Corin Throsby.

All paper used by Open Book Publishers is SFI (Sustainable Forestry Initiative), PEFC (Programme for the Endorsement of Forest Certification Schemes) and Forest Stewardship Council(r)(FSC(r) certified.

Printed in the United Kingdom, United States, and Australia by Lightning Source for Open Book Publishers (Cambridge, UK) 


\section{Contents}

Acknowledgments 1

Notes on Contributors 3

$\begin{array}{ll}\text { Introduction } & 7\end{array}$

Simon Franklin

\section{MAP-MAKING}

1. Early Mapping: The Tsardom in Manuscript Valerie Kivelson

2. New Technology and the Mapping of Empire:

The Adoption of the Astrolabe Aleksei Golubinskii

\section{INTERNATIONAL NEWS AND POST}

3. Muscovy and the European Information Revolution:

Creating the Mechanisms for Obtaining Foreign News

Daniel C. Waugh and Ingrid Maier

4. How Was Western Europe Informed about Muscovy?

The Razin Rebellion in Focus

Ingrid Maier

\section{NEWS AND POST IN RUSSIA}

5. Communication and Obligation: The Postal System of the Russian Empire, 1700-1850

John Randolph 
6. Information and Efficiency: Russian Newspapers, ca.1700-1850

Alison K. Smith

7. What Was News and How Was It Communicated in Pre-Modern Russia?

Daniel C. Waugh

\section{INSTITUTIONAL KNOWLEDGE AND COMMUNICATION}

8. Bureaucracy and Knowledge Creation: The Apothecary 255

Chancery Clare Griffin

9. What Could the Empress Know About Her Money? Russian Poll Tax Revenues in the Eighteenth Century Elena Korchmina

10. Communication and Official Enlightenment: The Journal of the Ministry of Public Education, 1834-1855

Ekaterina Basargina

\section{INFORMATION AND PUBLIC DISPLAY}

11. Information in Plain Sight: The Formation of the Public Graphosphere Simon Franklin

12. Experiencing Information: An Early Nineteenth-Century 369 Stroll Along Nevskii Prospekt

Katherine Bowers

Selected Further Reading 


\section{IV. \\ INSTITUTIONAL KNOWLEDGE AND COMMUNICATION}





\title{
8. Bureaucracy and Knowledge Creation: The Apothecary Chancery
}

\author{
Clare Griffin ${ }^{1}$
}

In 1628, physicians in the Russian palace's medical department were presented with a root, and ordered to give their opinion on it. ${ }^{2}$ The root in question had been taken as evidence in a witchcraft case, as possession of herbs and roots was commonly seen as evidence of malefic magic

1 This chapter started life as a part of my Ph.D. dissertation, before undergoing a number of transformations, aided at every stage by the kindness and generosity of funders and colleagues, into its present state. I would like to thank the Arts and Humanities Research Council, who funded my graduate work, the Wellcome Trust and the Max Planck Institute for the History of Science, Berlin, who have funded my postdoctoral work, for their financial support. Endless comments, criticisms, suggestions, revisions, and improvements to this chapter-and its previous incarnations - were suggested by a great number of colleagues during my Ph.D. work, the workshop from which this volume emerged, and the Pre-Modern Conversation Seminar Series at the Max Planck Institute for the History of Science, and in particular by Sergei Bogatyrev, Harold J. Cook, Simon Dixon, Sebastian Felten, Lauren Kassell, Elaine Leong, Martyn Rady, and Faith Wigzell, as well as the three anonymous peer reviewers of the present volume. My thanks also go, as ever, to the staff of the Russian State Archive of Ancient Documents (RGADA), Moscow, for the use of their materials, and for the wonderful work they do. Finally, thanks also to our tireless editors, Simon and Katia, without whom this chapter would have been much less than it is. All remaining mistakes and deficiencies are entirely my own.

2 N. Ia. Novombergskii, Materialy po istorii meditsiny v Rossii, 5 vols (St Petersburg: M. M. Stasiulevich, 1905), 3. 1, pp. 9-12. This case is discussed in Eve Levin, 'Healers and Witches in Early Modern Russia', in Saluting Aron Gurevich: Essays in History, Literature, and Other Related Subjects, ed. by Yelena Mazour-Matusevich and Alexandra S. Korros (Leiden: Brill, 2010), pp. 105-33 (pp. 117-18). For an analysis of how the documentary process worked in Russian witchcraft trials in general, see Valerie Kivelson, Desperate Magic: The Moral Economy of Witchcraft in SeventeenthCentury Russia (Ithaca and London: Cornell University Press, 2013), pp. 38-51. 
in seventeenth-century Russia. So the medical experts-foreigners, and graduates of prestigious Western European universities-spoke in Latin on the medical and magical properties of this root, a response that was translated and taken down in Russian, and then sent from the medical department to the Military Service Chancery (Razriadnyi prikaz), the department handling the case, and from whom the order for the report had been received. This was by no means an unusual event: the medical experts of the Apothecary Chancery, as the seventeenthcentury Russian palace medical department was called, were commonly called upon to compose learned reports for their own department, the tsar, and other parts of the Muscovite administration. Reports covered a range of subjects: autopsies to establish cause of death, "physicals" of servitors to see if they were still fit to serve, investigations into the private trade in medical drugs, proposed courses of treatments, notes regarding unsuccessful treatments, and considerations of illnesses, medicines, and medical practices. In every case, Russian bureaucrats posed a specific, practical question; medical experts answered orally or in writing in Latin, drawing on their expertise and their books; the answer was translated into Russian and circulated to the relevant bureaucrats in writing, but often read aloud; the further progress of the case at hand was decided in part on the basis of that expert knowledge; and the report was then stored within the relevant case-file. Such a process can be seen as an information technology. This term, widely used yet rarely explicitly defined, is most commonly used to refer to modern devices such as computers, but it has also been applied to early modern technologies such as printing. ${ }^{3}$ Discussions of the nature of information technologies revolve around a device or system's capacity not only to communicate a concept, but to reify it, making it storable. ${ }^{4}$ We can thus see information technology as a device or system which allows the encoding, recording, communication, storage, and retrieval of information, a definition which applies to computers, the printing press, paper technologies more generally, and, most significantly

3 See for example Jeremiah E. Dittmar, 'Information Technology and Economic Change: The Impact of the Printing Press', The Quarterly Journal of Economics, 126 (2011), 1133-72.

4 See Michael E. Hobart, and Zachary S. Schiffman, Information Ages: Literacy, Numeracy, and the Computer Revolution (Baltimore: Johns Hopkins University Press, 2000), especially pp. 4 and 212. 
here, the Apothecary Chancery's reporting system. The Apothecary Chancery's reports thus allows us to investigate knowledge circulation and information technologies in the context of seventeenth-century Russian administration, and in turn to see what the Russian case can reveal about information technologies in the early modern context.

\section{The Apothecary Chancery, the Chancery System, and Knowledge for the State}

The 1628 case concerning the potentially magical root involved documents being passed between the regional governor in Rzhevwhere the accused witch, Andrei Loptunov, had first been arrestedthe regional governor in Toropets, Loptunov's home town, the Moscow jail in which Loptunov was being held, the Military Service Chancery, who were investigating the case, and the Apothecary Chancery, who were providing expert testimony on the properties of said root. Such a circulation of documents was a feature of Muscovite administration. This administrative network, known as the chancery system, was composed of around sixty departments, or chanceries. Not all these departments were permanent fixtures, with some only lasting a matter of years, and yet the number of departments remained relatively constant across the century. ${ }^{5}$ Departments were created to deal with all significant areas of Muscovite life: finances and tax-collection; military affairs; administration of regions, especially those recently acquired; court life; and the Church. Where chanceries shared similar duties, close collaboration was necessary. For example, there were different chanceries responsible for general military and service activities, new formation regiments, and foreign mercenaries, all of whom had to cooperate to allow the Muscovite armed forces to function effectively. Alongside these central chanceries, Muscovy was also administered through the use of provincial governors, who communicated with the central chanceries on a number of issues. Chancery directors played a key role in this system, as conducting correspondence with other branches of the Muscovite governmental system was a vital part of their duties.

5 Peter B. Brown, 'How Muscovy Governed. Seventeenth-Century Russian Administration', Russian History, 36 (2009), 459-529 (p. 476). 


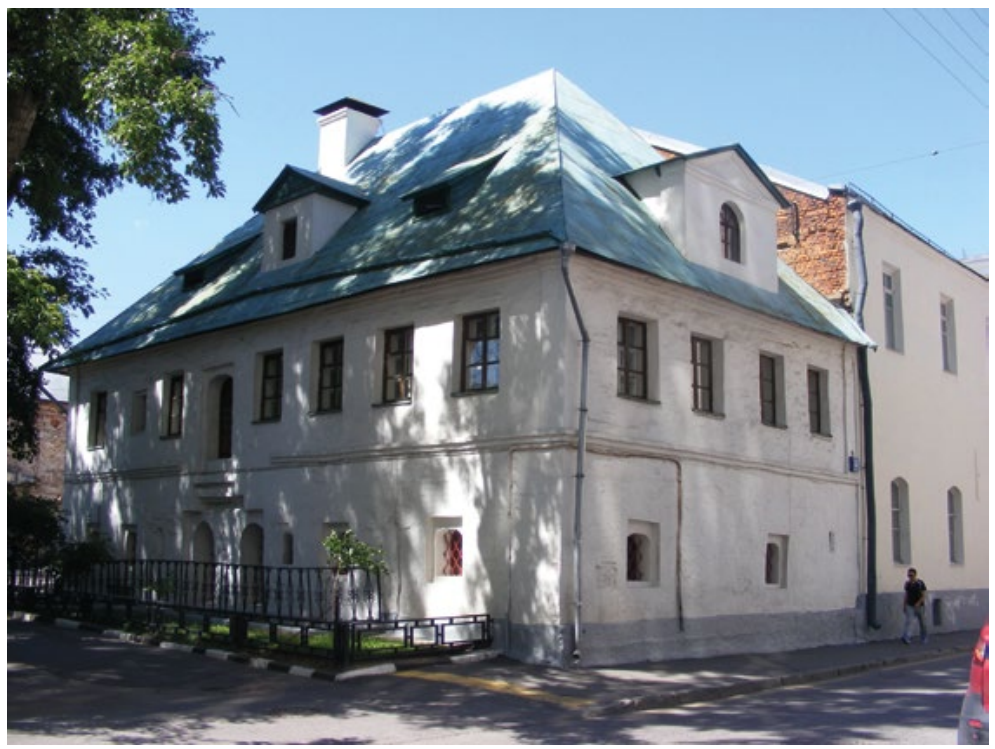

Figure 1. The Apothecary Chancery today.

The chancery directors were helped in their duties by the secretaries, another key group who undertook much of the day-to-day recordkeeping. Across the course of the seventeenth century there were significant changes in chancery staffing. N. F. Demidova has shown that the overall number of secretaries rose dramatically across the seventeenth century: in the 1640s, there were 837 secretaries and undersecretaries in central chanceries; by the 1680s, this number had risen to $2,739 .{ }^{6}$ The growth in secretary numbers identified by Demidova is consistent with the figures provided by Grigorii Karpovich Kotoshikhin (ca. 1630-67), a former chancery secretary who defected to Poland and, later, Sweden, and author of the only contemporary Russian account of the chancery system. During the 1660s, Kotoshikhin puts the numbers of secretaries and governors at 100, and the number of undersecretaries at 1000; consideration of his numbers would suggest that the numbers of secretaries rose most precipitously between the 1660s and the 1680s. ${ }^{7}$ Some departments were more reliant upon specialist staff than

6 N. F. Demidova, Sluzhilaia biurokratiia $v$ Rossii XVII $v$. i ee rol' $v$ formirovanii absoliutizma (Moscow: Nauka, 1987), p. 37.

7 G. K. Kotoshikhin, O Rossii v tsarstwovanie Alekseia Mikhailovicha (Moscow: ROSSPEN, 2000), p. 141. 
secretaries. The Apothecary Chancery only employed 2-3 secretaries at a time, with the vast majority of its staff consisting of medical practitioners. Like the secretaries, the numbers of medical practitioners employed at the Russian court rose dramatically across the seventeenth century. Figures compiled by Sabine Dumschat give the overall number of Apothecary Chancery medical staff in the period $1600-20$ as 17 ; by 1680-96 there were $112 .{ }^{8}$ This rise in staff numbers of both medical practitioners and secretaries is indicative of a general expansion of the chancery system across the seventeenth century.

The expansion of the chancery system necessitated and drove an institutionalised form of literacy. Literacy in seventeenth-century Russia was commonly seen as a specialised skill, and was largely (although by no means exclusively) restricted to those who read and wrote professionally, such as the administrators and monastic copyists. ${ }^{9}$ The chancery system, as it required the transmission of orders and information, relied heavily upon written documentation to perform its duties, leading to a proliferation of administrative documents. As departments communicated with one another, or with other government agents in Russia or abroad, written documents were used to ensure accurate transmission and to record those communications.

The chancery system produced and circulated a great variety of documents, each with its own name: petitions (chelobitnye gramoty pl., chelobitnaia gramota sg.); orders from the tsar (pl. ukazy, sg. ukaz), his counsellors (prigovory pl., prigovor sg.), and from department heads; communications between department heads (pamiati pl., pamiat' sg.); responses from underlings to their superiors confirming that they had fulfilled an order (otpiski pl., otpiska sg.); interrogation records (rassprossnye rechi pl., rassprosnaia rech' sng.); torture records (pytochnye rechi pl., pytochnaia rech' sng.); and reports such as those created by the Apothecary Chancery medical experts (skazki pl., skazka sg.). ${ }^{10}$

8 Sabine Dumschat, Ausländischer Mediziner im Moskauer Russland (Stuttgart: Franz Steiner Verlag, 2006), p. 104.

9 Clare Griffin, 'In Search of an Audience: Popular Pharmacies and the Limits of Literate Medicine in Late Seventeenth- and Early Eighteenth-Century Russia', Bulletin for the History of Medicine, 89 (2015), 705-32.

10 On the different kinds of document, see S. O. Shmidt and S. E. Kniaz'kov, Dokumenty deloproizvodstva pravitel'stvennykh uchrezhdenii Rossii XVI-XVII vv. Uchebnoe posobie (Moscow: MGIAI, 1985); O. F. Kozlov et al. Gosudarstvennost' Rossii: gosudarstvennye $i$ tserkovnye uchrezhdeniia, soslovnye organy $i$ organy mestnogo samoupravleniia, edinitsy administrativno-territorial'nogo, tserkovnogo i vedomstvennogo deleniia (konets $X V$ veka 
Some departments produced special kinds of document, like the VestiKuranty, a modern term for Russian translations of foreign newspapers produced by the Ambassadorial Chancery, and discussed elsewhere in this volume by Ingrid Maier and Daniel C. Waugh. A number of chanceries owned or produced books. The Ambassadorial Chancery produced a large number of translations, like Maciej Stryjkowski's Polish Chronicle. ${ }^{11}$ Simeon Ushakov, who worked in the Armoury (Oruzheinyi prikaz), proposed (although never completed) a manual on icon painting. ${ }^{12}$ Nikolai Diletskii produced a textbook of music theory to help musicians at the Russian court understand and compose music. ${ }^{13}$ The Apothecary Chancery owned a library of medical, natural historical and other miscellaneous books. ${ }^{14} \mathrm{~A}$ number of those medical works were translated, and in the later seventeenth century Apothecary Chancery employees also composed their own texts. ${ }^{15} \mathrm{~A}$ central feature of the chancery system was thus its production, storage and circulation of documents.

In the historiography of the chancery system as a whole, and in the historiography of individual chanceries, the issue of function has always been seen as important. Attempts have been made to classify the

-fevral' 1917 goda): slovar'-spravochnik, 6 vols (Moscow: Nauka, 1996-2009); Peter B. Brown, 'Early Modern Russian Bureaucracy: The Evolution of the Chancellery System From Ivan III to Peter the Great' (Ph.D. dissertation, University of Chicago, 1978), pp. 147-58; M. N. Tikhomirov, Rossiiskoe gosudarstvo XV-XVII vekov (Moscow: Nauka, 1973), pp. 364-69.

11 Christine Watson, Tradition and Translation: Maciej Stryjkowski's Polish Chronicle in Seventeenth-Century Russian Manuscripts, Studia Slavica Upsaliensia XXXXVI (Uppsala: Acta Universitatis Upsaliensis, 2012).

12 Lindsey Hughes, 'The Moscow Armory and Innovations in Seventeenth-Century Muscovite Art', Canadian-American Slavic Studies, 13 (1979), 204-23.

13 Claudia R. Jensen, Musical Cultures in Seventeenth-Century Russia (Bloomington and Indianapolis: Indiana University Press, 2009), pp. 122-23, p. 277, n. 54.

14 Katalog knig iz sobraniia Aptekarskogo prikaza, ed. by E. A. Savel'eva (St Petersburg: Al'faret, 2006), pp. 19-25. See also M. I. Slukhovskii, Bibliotechnoe delo $v$ Rossii do XVII veka. Iz istorii knizhnogo prosveshcheniia (Moscow: Kniga, 1968), pp. 87-89; S. P. Luppov, Kniga v Rossii v XVII veke (Leningrad: Nauka, 1970), pp. 203-08.

15 On the translation of medical texts by the Apothecary Chancery, see 1672 translation of a German medical book, L. F. Zmeev, Russkie vrachebniki. Issledovanie v oblasti nashei drevnei vrachebnoi pis'mennosti, Pamiatniki drevnei pis'mennosti i iskusstva, no. 112 (St Petersburg: [n. pub.], 1896), pp. 72-73. In 1679 ten medical books were ordered to be translated, RGADA, coll. 143, descr. 2, file 1290. On the lack of a translator hampering translation work in the Apothecary Chancery: Mamonov, Materialy, 4, pp. 989-94. On the compilation of medical texts by the Apothecary Chancery staff see Griffin, 'In Search of an Audience'. 
chanceries, by dividing them up into their relative spheres. ${ }^{16}$ Eve Levin, Maria Unkovskaya, and a number of historians of the chancery system have all proposed that the Apothecary Chancery was either exclusively or primarily a court institution. ${ }^{17}$ This view is particularly dependent upon the treatment of patients undertaken by the Apothecary Chancery: a substantial proportion of patients were members of court, therefore the Apothecary Chancery was a court institution. It should be noted, however, that the department also provided medical services for the army from at least $1632 .{ }^{18}$ Other scholars of the Apothecary Chancery have seen it as having a somewhat wider purview: M. B. Mirskii highlighted the fact that the Apothecary Chancery had some responsibility for the health of Muscovites outside of court circles and the army; M. K. Sokolovskii described the department as acting in several capacities, including as an Academy of Sciences, referring to both its library and its production of reports. ${ }^{19}$ Such approaches are in line with the views of K. A. Nevolin, who suggested that the Apothecary Chancery was defined by its function, medicine, not by its relationship to the court. ${ }^{20}$ In such a schema, then, the Apothecary Chancery is commonly seen as a court department, concerned primarily or exclusively with the medical needs

16 For a detailed analysis of this historiographical trend, see Peter B. Brown, 'Muscovite Government Bureaus', Russian History, 10 (1983), 269-330.

17 D. V. Liseitsev, N. M. Rogozhin and Iu. M. Eskin, Prikazy Moskovskogo gosudarstva XVI-XVII vv. Slovar'-spravochnik (Moscow and St Petersburg: Tsentr gumanitarnikh initsiativ, 2015), pp. 33-35; Eve Levin, 'The Administration of Western Medicine in Seventeenth-Century Russia', in Modernizing Muscovy: Reform and Social Change in Seventeenth Century Russia, ed. by Jarmo Kotilaine and Marshall Poe (London and New York: Routledge Curzon, 2004), pp. 363-89 (pp. 366-67); Maria Unkovskaya, 'Learning Foreign Mysteries: Russian Pupils of the Aptekarskii Prikaz, 1650-1700', Oxford Slavonic Papers, 30 (1997), 1-20 (p. 2); N. V. Ustiugov, 'Evoliutsiia prikaznogo stroia russkogo gosudarstva v XVII v.', in Absoliutizm v Rossii XVII-XVIII vv: Sbornik statei $k$ semidesiatiletiiu so dnia rozhdeniia $i$ sorokapiatiletiiu nauchnoi i pedagogicheskoi deiatel'nosti B. B. Kafengauza, ed. by N. M. Druzhinin (Moscow: Nauka, 1964), 134-67 (p. 146); Brown, 'Muscovite Government Bureaus', pp. 292, 94.

181632 provision of medicines and field surgeons to the army: RGADA, coll. 143, descr. 1, file 114.

19 M. B. Mirskii, 'Aptekarskii prikaz (k 410-letiiu gosudarstvennogo upravleniia meditsinskimi delami v Rossii)', Sovetskoe zdravookhranenie, 11 (1991), $72-77$ (pp. 74-76); M. K. Sokolovskii, 'Kharakter i znachenie deiatel'nosti Aptekarskogo prikaza', Vestnik arkheologii i istorii, 16 (1904), 60-89 (pp. 60-61).

20 K. A. Nevolin, Polnoe sobranie sochinenii K. A. Nevolina, 6 vols (St Petersburg: Tip. Eduarda Pratsa, 1857-59), 6 (1859), pp. 143-44, 168. 
of the palace, with little or no competencies outside of those duties. ${ }^{21}$ However, such an analysis excludes or undervalues certain aspects of the Apothecary Chancery's work. Most importantly for our purposes here, the Apothecary Chancery was frequently called upon to provide reports to various institutions..$^{22}$ What, then, does this reporting work tell us about the function of the Apothecary Chancery, and about the functioning of the chancery system as a whole?

Work on information technologies, information management, paper technologies, and paperwork provide useful models here. The study of information in early modern Western Europe has focussed on the idea of an 'information overload', that early modern Europeans had access to an impossibly large amount of information, hence much intellectual work of the period was directed towards sorting, categorising, preserving and managing that information. This problem was particularly acute for two groups: experts and bureaucrats, the same groups involved in the Apothecary Chancery reporting system. This literature reveals the great variety of ways in which early modern Europeans sought to organise information: Ann Blair has written about manuscript notes and printed reference books; Anke Te Heesen has emphasised the influence and various utilities of double-entry book-keeping; various medical historians have looked at case-books; and Staffan Müller-Wille and Isabelle Charmantier have looked at the great Swedish botanist Carl Linnaeus's use of index cards. ${ }^{23}$ All these historians focus on the issue

21 N. P. Zagoskin, Vrachi i vrachebnoe delo v starinnoi Rossii (Kazan: Tip. Imperatorskogo Universiteta, 1891), p. 5; F. L. German, Kak lechilis' Moskovskie tsari? (medikoistoricheskii ocherk) (Kiev and Kharkov: F. A. Iorganson, 1895), p. 79; N. Ia. Novombergskii, Cherty vrachebnoi praktiki v Moskovskoi Rusi (kul'turno-istoricheskii ocherk) (St Petersburg: Tip. Ministerstva vnutrennikh del, 1904), pp. 53-54; N. V. Ustiugov, 'Evoliutsiia', p. 146; Brown, 'Muscovite Government Bureaus', pp. 292, 94; John Appleby, 'Ivan the Terrible to Peter the Great: British Formative Influence on Russia's Medico-Apothecary System', Medical History, 27 (1983), 289-304 (p. 290); Mirskii, 'Aptekarskii prikaz', p. 74-76; Unkovskaya, 'Learning Foreign Mysteries', p. 2; Levin, 'Administration', pp. 366-67; N. V. Rybalko, Rossiiskaia prikaznaia biurokratiia v smutnoe vremia nachala XVII v. (Moscow: Kvadriga, 2011), p. 12.

22 Sokolovskii, 'Kharakter i znachenie', pp. 60-61. Nevolin, Polnoe sobranie sochinenii, 6, pp. 143-44, 168.

23 Ann M. Blair, Too Much to Know: Managing Scholarly Information Before The Modern Age (New Haven: Yale University Press, 2010); Staffan Müller-Wille, and Isabelle Charmantier, 'Natural History and Information Overload: The Case of Linnaeus', Studies in History and Philosophy of Science Part C: Studies in History and Philosophy of Biological and Biomedical Sciences, 43 (2012), 4-15; Anke Te Heesen, 'Accounting for the Natural World: Double-Entry Bookkeeping in the Field', in Colonial Botany: 
of paper, manuscript and print, either singularly or in interaction. Paper was also vital to the Apothecary Chancery, and indeed the chancery system as a whole. Yet following the path of Apothecary Chancery reports highlights another issue: the spoken word as a meaningful part of how knowledge was created and circulated. ${ }^{24}$ Orders for reports to be made were given orally; reports were either written down immediately, or spoken out loud and then transcribed; they were conveyed to bureaucrats in speech. Oral communication was a fundamental, inalienable part of the system. This is an aspect of knowledge exchange the focus on paper tends to obscure: although orality has been discussed as a part of early modern scientific exchange, it is not seen as an integral part of early modern scientific information technologies. ${ }^{25}$ Here, then, we will use the term information technology, rather than paper technology, to highlight that it is the information-the reports - that we choose to follow and to highlight, and not the paper. The concept of information technology gives us a new way to approach the chancery system, one which focuses on how departments worked together, rather than what divided them; conversely, the Russian case highlights the interactions of paper with speech as a fundamental part of knowledge circulation.

\section{Ordering Knowledge}

Before the questionable root found on Loptunov in 1628 was sent to the Apothecary Chancery, Loptunov himself had been interrogated regarding his possession, where he stated

the root he had wrapped around a crucifix was given to him by a passer-by on the road, and from which town [this man came] he does

Science, Commerce, And Politics in the Early Modern World, ed. by Londa Schiebinger, and Claudia Swan (Philadelphia: University of Pennsylvania Press, 2005), pp. 237-51.

24 The utility of orality in Muscovy has been discussed by Christoph Witzenrath. See Witzenrath, 'Literacy and Orality in the Eurasian Frontier: Imperial Culture and Space in Seventeenth-Century Siberia and Russia', Slavonic and East European Review, 87. 1 (2009), 53-77.

25 See for example Eileen Adair Reeves, 'Speaking of Sunspots: Oral Culture in an Early Modern Scientific Exchange', Configurations, 13 (2007), 185-210; Walter J. Ong, 'Orality, Literacy, and Medieval Textualization', New Literary History, 16 (1984), $1-12$. 
not know, and [the man] gave him that root because Andrei suffers from epilepsy [lit. black illness]. ${ }^{26}$

It was Loptunov's claim that the root was medical, and not magical, that led to the involvement of the Apothecary Chancery, but it was not Loptunov's decision. Counsellor Secretary Fedor Fedorovich Likhachev, head of the Military Service Chancery and so the man ultimately responsible for Loptunov's trial, was the person who ordered the report, sending both root and order to the Apothecary Chancery. At the Apothecary Chancery, Likhachev's order was then affirmed and reiterated by the director, boyar prince Ivan Borisovich Cherkasskii. Such a process was typical for the creation of Apothecary Chancery reports: their writing was ordered by a senior Russian bureaucrat, who was commonly a noble.

The role of a noble official in ordering reports relates to the issue of boyar involvement in chancery affairs, a topic that has been controversial. One substantial issue is the education of Russian nobles: not all of them were functionally literate, and certainly none of the Apothecary Chancery directors had any medical training. How, then, could they have contributed to the administration of a literate bureaucracy, especially when it dealt with expert knowledge? Borivoj Plavsic has proposed that the boyars did little in the chanceries, with the real work being done by the secretaries, who worked as their assistants. ${ }^{27}$ Robert O. Crummey has a more positive view of the boyars' contribution, proposing that they would have used their long tradition of military service to bring much needed leadership to chancery affairs. ${ }^{28}$ Crummey, however, does not think that the boyars made a practical contribution based on skill. Peter B. Brown has proposed a third view: looking at the organisation and work of the Military Service Chancery, he notes that this institution

26 Novombergskii, Materialy, 3. 1, pp. 9-12; V. B. Kolosova, 'Name-Text-Ritual: The Role of Plant Characteristics in Slavic Folk Medicine', Folklorica, 10 (2005), $44-61$ (p. 52).

27 Borivoj Plavsic, 'Seventeenth-Century Chanceries and Their Staffs', in Russian Officialdom: The Bureaucratization of Russian Society from the Seventeenth to the Twentieth Century, ed. by Walter McKenzie Pintner and Don Karl Rowney (London: Macmillan, 1980), pp. 19-45 (pp. 25-26).

28 Robert O. Crummey, 'The Origins of the Noble Official: The Boyar Elite, 1613-1689', in Russian Officialdom, ed. by Pintner and Rowney, pp. 46-75 (p. 75). 
fulfilled its duties competently, which reflects well on the boyars. ${ }^{29}$ Similarly, George G. Weickhardt has argued that, judging by their successes and failures during the seventeenth century, there was no clear difference in the competence of the boyars and the secretaries. ${ }^{30}$ Apothecary Chancery directors, who before 1696 were all boyars, always had substantial administrative experience in other departments before taking up that post. ${ }^{31}$ It thus seems that boyar directors were expected to take active part in the administration of their departments, which, in the case of the Apothecary Chancery, included ordering reports. Indeed, as such an order could be conveyed orally, there is no reason that functional illiteracy would have been an issue. Russian boyars formed a vital, initial stage in the information technology of Apothecary Chancery reports.

Not all extant Apothecary Chancery reports have retained their initial pages, meaning it is not always known exactly which Russian official ordered the report. Such preliminary pages survive in enough reports to show that very commonly such orders came from the Apothecary Chancery director. Such was the case in 1643, when head of the Apothecary Chancery, Fedor Ivanovich Sheremetev, asked the German physician Belau for a report explaining his treatment of Grigorii Gorikhvostov for worms. ${ }^{32}$ When Sheremetev asked for the report, Gorikhvostov had been under Belau's care for a month; apparently, this was considered to be too long, and Belau was called upon to explain why his treatment had failed to produce results. Here Sheremetev was evidently concerned with the efficiency and efficacy of patient treatment in the department, a problem he sought to resolve partly through the production of knowledge. Similar reports ordered by the Apothecary Chancery director concern cooling

29 Peter B. Brown, 'Military Planning and High-Level Decision-Making in SeventeenthCentury Russia: The Roles of the Military Chancellery (Razriad) and the Boyar Duma', Forschungen zur osteuropäischen Geschichte, 58 (2002), 33-43.

30 George G. Weickhardt, 'Bureaucrats and Boiars in the Muscovite Tsardom', Russian History, 10 (1983), 342-49 (pp. 347-49).

31 For an overview of the careers of Apothecary Chancery directors, see Clare Griffin, 'The Production and Consumption of Medical Knowledge in Seventeenth-Century Russia: The Apothecary Chancery' (Ph.D. dissertation, University College London, 2013), pp. 221-23, http://discovery.ucl.ac.uk/1388075/

32 Unusually for an Apothecary Chancery document, we are not given any further information about Gorikhvostov other than his name. Mamonov, Materialy, 1, pp. $39-40$. 
medicines (1643), and autopsies (1677, and 1679). ${ }^{33}$ Orders from the Apothecary Chancery head commonly dealt with strictly medical matters.

Orders for reports could come directly from the ruler. Between 1619 and 1633, Patriarch Filaret was co-ruler with his son, Tsar Mikhail Fedorovich, and Filaret himself commissioned certain reports. In 1623 Filaret launched an investigation into Mikhail Fedorovich's former fiancée, Mariia Ivanovna Khlopova, in particular concerning her sudden sickness that had ended the engagment in 1616; the investigation included an Apothecary Chancery report on her health. ${ }^{34}$ In 1644 a member of the retinue of Count Valdemar (son of King Christian IV of Denmark by morganatic marriage) was killed when Valdemar attempted to flee Moscow to escape the stalled negotiations to marry Tsarevna Irina. As a result, Tsar Mikhail Fedorovich ordered an official autopsy be conducted on the luckless Danish servitor. ${ }^{35}$ An order from Tsar Aleksei Mikhailovich in 1679 calls for an autopsy of boyar prince Ivan Alekseevich Vorotynskii, who had died suddenly shortly after a meeting with the tsar, raising the possibility that the tsar had been infected with a deadly disease. ${ }^{36}$ Orders from the tsar or his co-rulers also concerned medicine, but as a way to solve political problems.

Even when the order came from the Apothecary Chancery director, there is often direct or indirect evidence that the tsar was involved in the process. In 1645 Count Valdemar again came to the attention of the Apothecary Chancery, as he had requested some medicines from the department; Apothecary Chancery director Fedor Ivanovich Sheremetev ordered a report on which illnesses such medicines could be used to treat. ${ }^{37}$ Given the tsar's interest in his potential son-in-law and heir (Mikhail only had one son, the future Tsar Alexei Mikhailovich, not a sure dynastic bet, and Valdemar's parents' morganatic marriage meant he could not claim the Danish throne), it is likely he was involved in this case. Another significant group of reports involving the tsar concern negotiations

331643 report on cooling medicines: Mamonov, Materialy, 1, pp. 45-46. 1677 report on Blumentrost's wife and daughter: Mamonov, Materialy, 4, pp. 908. 1679 report on the Patriarch's groom: Mamonov, Materialy, 4, pp. 1161-62.

34 Sobranie gosudarstvennykh gramot $i$ dogovorov, khraniashchikhsia $v$ gosudarstvennoi kollegii inostrannykh del, 4 vols (Moscow: N. S. Vsevolozhskii, 1813-28), 3, pp. 257-66.

35 Mamonov, Materialy, 1, pp. 62-63.

36 Mamonov, Materialy, 4, pp. 1304, 1198-99.

37 Mamonov, Materialy, 1, p. 125. 
over the purchase of unicorn horns. ${ }^{38}$ Unicorn horns, most of which were actually narwhal tusks, were a prized - and hugely expensivecommodity, sought after both as ornaments and as medicaments in early modern Europe. ${ }^{39}$ During the course of purchase negotiations in 1657, the Apothecary Chancery head relayed the tsar's order that reports be produced, on the specific horn in question, and on unicorn horn and its medical properties in general. ${ }^{40}$ Orders relayed from the tsar via the Apothecary Chancery director thus also commonly focus on politics, but sometimes also concerned expensive medicines.

The Apothecary Chancery also received orders to produce reports from other sections of the Muscovite administrative system. One of the largest groups of such documents is the examinations of soldiers and other servitors to assess their fitness to serve. In such cases, Apothecary Chancery physicians were tasked with three questions: was the servitor genuinely sick, injured, or otherwise incapacitated; could the ailment be treated; and, once treatment was completed, could the service person in question return to his duties. For example, in 1666 the Musketeers' Chancery had a group of their servitors examined, with the Apothecary Chancery report detailing the bodily state of each man and how it related to their ability to serve. ${ }^{41}$ Notably, the document does not record any actual treatments, only information on the necessity and possible outcomes of any future treatments. The military departments thus were involved in ordering reports relating to the usefulness of servitors' bodies.

As in the case with which we began, the 1628 witchcraft investigation, reports were also requested as a part of judicial proceedings conducted by various chanceries. Such reports always explicitly state the limits of the report, posing a specific question for the experts to answer. In 1657, the Apothecary Chancery was sent a herb and asked "what is

38 These reports are discussed in Robert Collis, 'Magic, Medicine and Authority in Mid-Seventeenth-Century Muscovy: Andreas Engelhardt (d. 1683) and the Role of the Western Physician at the Court of Tsar Aleksei Mikhailovich, 1656-1666', Russian History, 40 (2013), 399-427.

39 On the use of unicorn horn as an objet d'art, see Aleksandr Plukowski, 'Narwhals or Unicorns? Exotic Animals as Material Culture in Medieval Europe', European Journal of Archaeology, 7 (2004), 291-313. On the use of the horn in medicine, see Brian Fotheringham, 'The Unicorn and its Influence on Pharmacy and Medicine', Pharmacy History Australia, 10 (2000), 3-7.

40 Mamonov, Materialy, 2, p. 160.

41 Ibid., pp. 311-12. 
that herb and is it criminal (vorovskoe)?" - criminal being a common synonym for maleficia, or magic intended to cause harm. ${ }^{42}$ In a case from 1703 , the physicians were asked "whether that root is evil, or good, or good for the aforementioned illness, and is useful for medicine" ${ }^{43} \mathrm{~A}$ similar set of orders concern illicit medical practice. In 1685 the head of the Musketeers' Chancery, Counsellor Secretary Fedor Leontevich Shaklovityi, requested a report from the Apothecary Chancery on the herb p'ianoe zelie (lit. heady herb), which was being sold on the market stalls (zelenyi riad, herb row) as a medicine. ${ }^{44}$ As with the orders relating to witchcraft cases, Shaklovityi wanted to know if this herb had been licenced for sale (i poskolko ego veleno prodavat is porukoiu l' ili bes poruk), and if this herb was appropriate for use as an internal medicine. Reports ordered for inclusion in trials thus focus on the physical evidence upon which the decision of the case rested.

Non-expert, noble officials from across the Muscovite administration played a central role in both initiating, and determining the limits, of Apothecary Chancery report production. They set the questions upon which the reports were to be focussed and initiated the exchange of documents around the administration, which was also an essential part of the process. The limits of expert medical reports, and the nature of the chancery system as an information technology, was determined by Russian bureaucrats, not by medical experts.

\section{Compiling Knowledge}

Returning again to 1628, the Military Service Chancery, having heard the testimony of both Loptunov and his master, decided on further tests of Andrei's story, and his characterisation of the root as medicinal, by sending the root to the Apothecary Chancery for examination. The resulting report states,

Doctor Valentine [Bills] and his colleagues, having looked at the root, said that this root [is called] Goose-flesh, and is used in medicines, and has nothing evil in it, and [people] put that root in the mouth. And if someone wished to commit a crime, and [if] he used the good herb

421657 witchcraft case against Andrei Durbenev: Mamonov, Materialy, 3, 676-77.

43 RGADA, coll. 143, descr. 2, file 1618.

441685 investigation into the sale of p'ianoe zelie: RGADA, coll. 143, descr. 3, file 172. 
badly, for criminality or witchcraft, that they do not know, [and they do not know] if there is a curse on that root. ${ }^{45}$

In this case, the report was created in part by an examination of a natural object. That examination was informed by the expertise of the physicians, and their ability to identify a root and to know and recount its properties, based on the training in botany and natural history that Western European university-trained physicians possessed. This process of selecting brief snippets of information from a much larger corpus of knowledge in order to give a focussed answer to a specific question was central to the Apothecary Chancery reporting system.

Reports created from a combination of experience and expert knowledge made up a substantial proportion of such texts, with particular emphasis on natural objects and human bodies. All of the reports produced for witchcraft and medical malpractice trials involved such examinations, usually of herbs and roots. Interestingly, these were the only cases in which Russians played a role as experts rather than patrons. Until 1654, all medical practitioners were foreigners from Western Europe. After that date, the Apothecary Chancery began to train medical practitioners for the first time: field surgeons, to serve the army; and apothecaries, to prepare medicines. ${ }^{46}$ The department also employed Russians as herb collectors (travniki) who were expected to be knowledgeable in the properties of local plants. These Russian medical practitioners occasionally took part in report creation. In the 1685 p'ianoe zelie case all the examiners were foreign medical practitioners. ${ }^{47}$ With one exception (1703), all of the medical experts who composed testimony for witchcraft trials were foreign. ${ }^{48}$ In contrast, in a 1679 medical malpractice case two separate groups of experts were consulted, the first group being led by foreigners, and the second group entirely consisting of Russians. ${ }^{49}$ Examination of a natural object was often a central part of the report-creation process, and in cases involving herbs and roots, Russians played a role in creating knowledge, as well as ordering it.

45 Novombergskii, Materialy, 3, part 1, pp. 9-12.

46 Unkovskaya, 'Foreign Mysteries', p. 12; Zmeev, Vrachebniki, p. 266; V. F. Gruzdev, Russkie rukopisnye travniki (Leningrad: Voenno-morskaia meditsinskaia akademiia, 1946), p. 25.

471685 malpractice case: RGADA, coll. 143, descr. 3, file 172.

481703 witchcraft cases: RGADA, coll. 143, descr. 2, file 1618.

491679 malpractice case: Mamonov, Materialy, 4, pp. 1110-11. 
A second substantial group of examination-based reports involved human bodies. Such was the case with post-mortems, for example that of the unfortunate Danish servitor killed in 1644 . The report on his cause of death stated "that cupbearer is wounded by a harquebus [and] the wound is just under the right eye". ${ }^{50}$ Unusually for post-mortems in Muscovy, the doctors then went on to attempt to remove the bullet by cutting into the body: such incisions were rarely made. In this case the incision was unproductive, as the bullet failed to materialise, with the doctors proposing that it likely had gone too deep into the skull to be easily retrieved. Whether a post-mortem included an internal probe, as in this case, or was only external, close examination of the body was key to creating the report.

As well as examining natural objects and human bodies whose state was in question, Apothecary Chancery medical experts also referred to books in making their reports. In such cases, the only experts involved were foreigners, although the Apothecary Chancery did own Russianlanguage texts. The use of books was made explicit in the 1685 report on the questionable herb p'ianoe zelie, as the Apothecary Chancery experts declared it unfit for use in internal medicine after an examination of texts in the Apothecary Chancery library revealed that it was not listed as medicinal. ${ }^{51}$ The report further added that $p^{\prime}$ ianoe zelie was a dangerous herb, capable of causing amnesia (zabvenie uma) and even death; such information may well also have been taken from a book..$^{52}$ In this case, multiple works from the Apothecary Chancery library were apparently used to construct the report.

Many reports mention individual authors and authorities. Samuel Collins's 1664 report on obesity cites Hippocrates. ${ }^{53}$ Andreas Lichifinus's 1657 report on the Indian unicorn references both Marco Polo and Andrea Bacci, a sixteenth-century papal physician. ${ }^{54}$ In Laurentius Blumentrost's 1690 report on the education of medical graduates from Padua (one of whom was then seeking a position in the department), he praised their knowledge of Galen and humoural medicine, but railed

50 Mamonov, Materialy, 1, pp. 62-63.

51 'v optekarskom prikaze $\mathrm{v}$ optekarskikh kn[i]gakh nigde ne napisana chtob ivo vnutr ch[e][[o]v[e]komu upotrebliat', RGADA, coll. 143, descr. 3, file 172.

52 RGADA, coll. 143, descr. 3, file 172.

53 Mamonov, Materialy, 3, pp. 787-89.

54 Mamonov, Materialy, 2, p. 160. 
against their ignorance of chemical medicine, a practice he ascribed not only to Paracelsus and Jan Baptist von Helmont (two of the most important chemical medical thinkers of early modern Europe), but also Hippocrates, Plato, and "other most ancient teachers, who are now and from ancient [times] accepted and respected" ${ }^{55}$ In this case, like Collins and Lichifinus before him, Blumentrost only makes mention of specific elements of a huge corpus of writing and ideas, selecting only the parts which make sense in the context of his report. Books and their authoritative and expert authors were important to Apothecary Chancery reports, but only small pieces of information were chosen from a vast amount of available and relevant medical and natural historical thought in order to craft a direct, expert answer to a particular question.

On rare occasions, Apothecary Chancery reports even delved into the Bible as a form of textual authority. The Latin version of Samuel Collins's report on venesection, written in 1664, contains several Biblical references. ${ }^{56}$ In creating an apologia for astrology as both medically useful and acceptable to Christianity, Collins included three Biblical quotations: Daniel 5. 27, Job 38. 31, and Judges 5. 20. All these quotations deal with God as an interventionist force in the universe, manipulating it according to his will and leaving signs for Christians to interpret. A marginal comment by Collins references the first century RomanJewish scholar Flavius Josephus, on Seth, the third son of Adam and Eve, to whom Josephus attributes the discovery of many of the secrets of astronomy. ${ }^{57}$ Here Collins took on two enormous corpora-the Bible, and Biblical scholarship - and, like his colleagues using other learned authorities, selected specific elements to support his argument. In this he was apparently unsuccessful: the Russian version of Collins's report excludes all these references, an issue dealt with below. Nevertheless, Collins's attempt to include in his report quotations from the most authoritative of all authorities in early modern Europe, the Bible, demonstrates the fundamental importance of brief, selective use of major textual authorities to create the Apothecary Chancery reports.

55 RGADA, coll. 143, descr. 3, file 322.

56 RGADA, coll. 143, descr. 2, file 738.

57 Flavius Josephus, The Antiquities of the Jews, trans. by William Whiston (Cirencester: The Echo Library, 2005), p. 444. 
In all of these cases the Apothecary Chancery reports took one, short, aspect of a larger textual authority, and re-contextualised it. Such an approach was by no means typical for early modern experts when dealing with information; they produced and reproduced information, and textual authority, in a variety of fashions. In perhaps the shortest format, Linnaeus placed individual words on index cards. ${ }^{58}$ At the other end of the scale, many intellectuals produced critical editions of ancient world texts in their entirety, often accompanied by substantial glosses, which could rival the length of the original work. Florilegia, miscellanies, botanical works, medical recipe books and natural histories all reproduced shorter textual elements, ranging from a paragraph to several pages of a chapter. ${ }^{59}$ The Apothecary Chancery's methods of dealing with textual authorities thus sat within a variety of approaches to such in the early modern world, which ranged from wholesale reproduction and even extension of the original, to the use of individual words. Considered in this context, Apothecary Chancery reports are notable for their selection of sentence-long pieces of information from textual authorities to be contextualised within longer prose compositions.

The creation of expert reports by the Apothecary Chancery was conducted on two bases, which often overlapped: examination of a natural object, and reference to established textual authorities. Interestingly, the only cases in which Russians worked as experts who created knowledge, rather than bureaucrats who ordered that knowledge be created, are those cases concerning examinations. It was the Western European, university-trained physicians who produced reports using textual authorities. The use of those authorities is hugely significant: the Hippocratic corpus, which comes up multiple times, is massive. Apothecary Chancery reports select only one or two elements from within this, and other extensive collections of writing, to create a selective, direct answer to a specific question.

58 Müller-Wille and Charmantier, 'Natural History and Information Overload'.

59 Blair, Too Much to Know. 


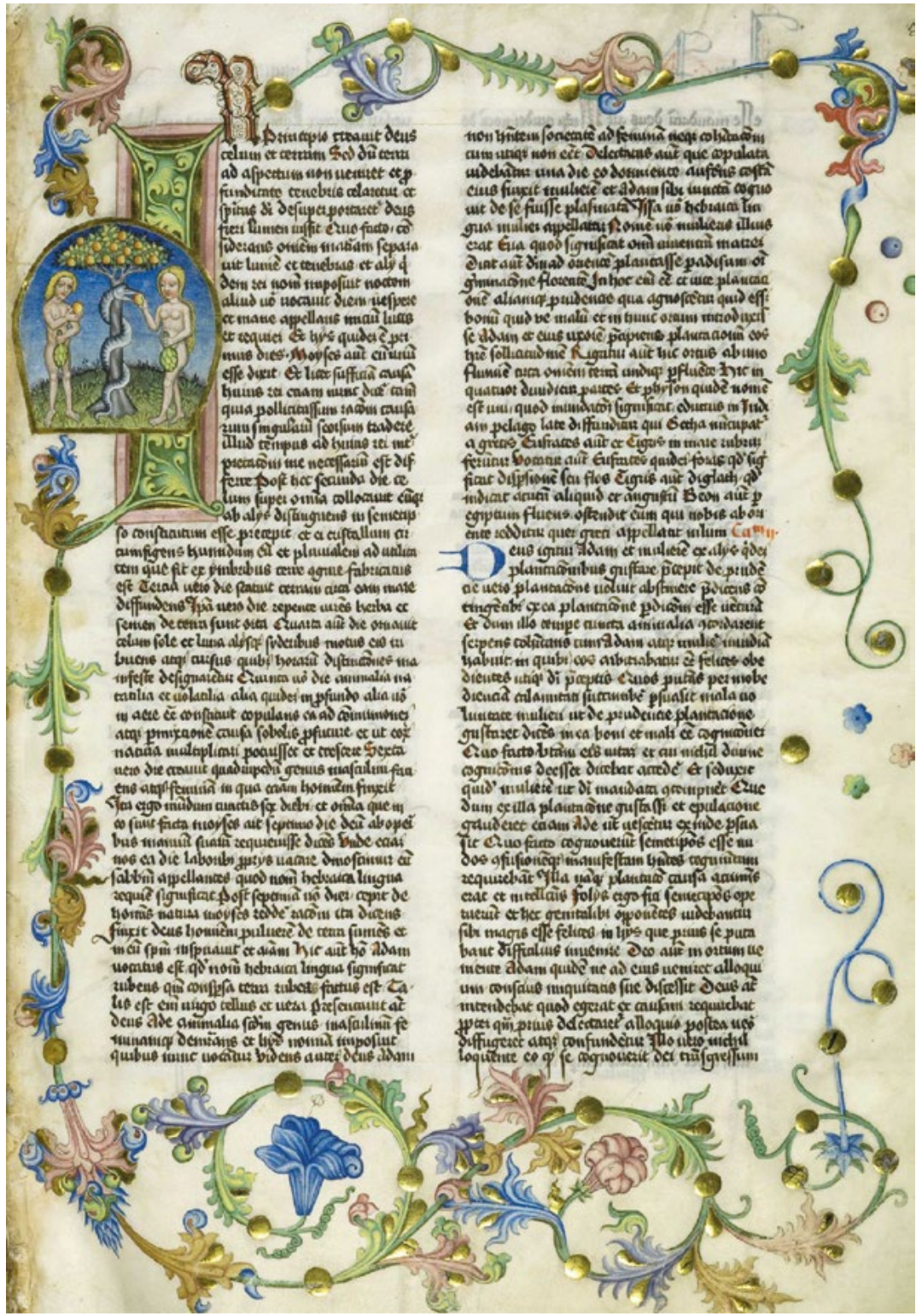

Figure 2. An illuminated page from Josephus's Antiquities of the Jews (1466). 


\section{Translating Knowledge}

A particular feature of knowledge circulation in the Apothecary Chancery was the central role of translation. The medical staff members were commonly native speakers of English, German or Dutch, although there were also occasionally French, Italian and Greek speakers present as well. Those trained in universities, such as the physicians, would have known Latin; those trained in guilds, such as apothecaries and surgeons, may not have done. Bureaucrats, both department heads and secretaries, were Russian speakers, only a few of whom knew foreign languages. This situation necessitated translation as a key part of knowledge exchange. This could take place as written translation, with the medical practitioners providing a Latin text, in which case the documents use the phrase "translated from a Latin document" (perevod $s$ Latinskogo pis'ma). It could also take place as an oral interpretation, with the Latin being spoken aloud, interpreted into Russian, and then taken down. In such cases, the verb "to say" (skazat' inf.) is used. Such was the case in Loptunov's 1628 witchcraft trial, in which the document records: "And Doctor Valentine [Bills] and his colleagues, having looked at the root, said [my emphasis]...". ${ }^{60}$

This was common, both within the Apothecary Chancery, and within the chancery system more widely: the same formulation is used in reports on cooling medicines ${ }^{61}$ and on worms ${ }^{62}$ in 1643 , a report on the uses of animal parts in medicine in $1664,{ }^{63}$ and autopsies in $1677^{64}$ and $1679 .{ }^{65}$ It is notable that all of these reports were particularly brief, even by the standards of the Apothecary Chancery: the autopsies, and the 1628 report on Loptunov's root, each run to only a few sentences; the other reports a couple of paragraphs. It thus seems that orally translated reports were made for particularly brief answers, when perhaps the process of composing a text and then translating it would have been unnecessarily time-consuming.

60 Novombergskii, Materialy, 3, part 1, pp. 9-12.

61 Mamonov, Materialy, 1, pp. 45-46.

62 Ibid., pp. 39-40.

63 Novombergskii, Materialy, 1, pp. 54-55.

641677 report on Blumentrost's wife and daughter: Mamonov, Materialy, 4, pp. 908.

651679 report on Patriarch's groom: Mamonov, Materialy, 4, pp. 1161-62. 
Transcription of oral reports could significantly shape the final form of the report. On 1 January 1658 a priest's wife was found dead, and three Apothecary Chancery physicians-Lichifinus, Engelhardt and Graman-examined the body for signs of plague. Engelhardt said: "That woman had scrofula of the stomach... and that [scrofula] does not cause the plague" ${ }^{66}$ Graman agreed, stating that: "That woman had scrofula of the stomach... and that [scrofula] does not cause the plague" ${ }^{67}$ A significant feature of these two statements is the high level of similarity between them; they are almost identical. It likely indicates that these were not the exact words of Engelhardt and Graman, as the sole difference between them is orthographical: variant spellings of the word for scrofula (zolotukha and zolotik). It is probable that the scribe reproducing Engelhardt's and Graman's statements paraphrased their words; as noted by Daniel E. Collins, such minor adjustments are common in other Muscovite documents that transcribe speech. ${ }^{68}$ Despite the lack of an original for comparison, we can nevertheless see that oral reports do seem to have been subject to adjustments by scribes.

The process of translation can be traced in greater detail when both an original and a translation are extant, as is the case in a number of the written reports. Significantly, although Apothecary Chancery medical staff spoke many languages, and even wrote some documents in other languages during their time in Russia (letters relating to their delays by officious border guards are typically written in German), all extant originals of the reports are in Latin. This was likely simply a practical consideration: reports were most commonly composed by the physicians, who all knew Latin; restricting the reporting to one language limited the numbers of translators the department required, which staff group was always in high demand across the chancery system.

The translation process was used to edit reports. As noted above, although Samuel Collins attempted to marshall Biblical authority in his defence of astrology as a useful and Christian activity, the sentences in which Collins references the Bible in his Latin original

66 Mamonov, Materialy, 3, pp. 694-95.

67 Ibid.

68 Daniel E. Collins, 'Speech Reporting and the Suppression of Orality in SeventeenthCentury Russian Trial Dossiers', Journal of Historical Pragmatics, 7 (2006), 265-92 (p. 283). See also Collins, Reanimated Voices. Speech Reporting in a Historical-Pragmatic Perspective (Amsterdam and Philadelphia: John Benjamins, 2001). 
were redacted in the Russian translation..$^{69}$ A. P. Bogdanov, who first noted that parts of the Latin original of this text were not preserved in the Russian translation, calls the removed sections insignificant (maloznachitel'nye). ${ }^{70}$ Alternatively, Maria Unkovskaya argues that the edited sentences were concerned with cosmology, and were not translated due to the ban she proposes existed in the Apothecary Chancery on the discussion of medical theory or natural philosophy. ${ }^{71}$ However, as shown in examples above, various other Apothecary Chancery reports do mention medical theorists, medical theories, and natural philosophy, often relying on works owned by the department. Moreover, sentences present in Collins's original Latin that are absent from the Russian are all Biblical, and not cosmological or natural philosophical. For example, Collins wrote

There is an ancient custom among the Persians, to which the Prophecy of Daniel in the presence of King Belshazzar may have referred with the word 'Tekel': You have been weighed on the scales and found wanting. [Emphasis my own]

The reference to Daniel's conversation with Belshazzar remains in the final Russian version, but Daniel's interpretation of the Word of God has been removed: you have been weighed, and found wanting (see Daniel 5. 13-28). In each case where sentences are removed, they were extracted from different parts of the text, in a way which leaves the remaining text comprehensible, but removes direct quotations from the Bible. This is likely due to concerns over heresy. In contrast to the highly adaptive approach to text and translation found in the Apothecary Chancery reports, and for that matter the Vesti-Kuranty, the text of the Bible and other religious works were approached entirely differently: the word, and the words, of God, were sacrosanct, and changing them was fundamentally problematic. ${ }^{72}$ This was evidenced by the problems of

69 RGADA, coll. 143, descr. 2, file 738.

70 A. P. Bogdanov, 'O rassuzhdenii Samuila Kollinsa', in Estestvennonauchnye predstavleniia Drevnei Rusi ed. by R. A. Simonov (Moscow: Nauka, 1988), pp. 204-08. Bogdanov's edition of the Russian text is published here pp. 206-08.

71 Unkovskaya, 'Foreign Mysteries', p. 9.

72 On adaptive translation in the Vesti-Kuranty, see Ingrid Maier, 'Newspaper Translations in Seventeenth-Century Muscovy. About the Sources, Topics and Periodicity of Kuranty "Made in Stockholm" (1649)', in Explorare necesse est. Hyllningsskrift till Barbro Nilsson, ed. by Per Ambrosiani, Elisabeth Löfstrand, 
Patriarch Nikon's Church reforms of the 1660s, which revolved around proposed changes to the service books. According to David Frick, many of those involved in the Muscovite religious debates were using Polish Bibles, but went to great lengths to conceal that fact. ${ }^{73}$ The Book of the Bible that Collins was citing here-Daniel-was in the Slavonic Bible, but Collins was not citing the Slavonic Bible; he was citing a Western European Bible. For Muscovites, this difference was substantial. The Slavonic Book of Daniel was canonical; a Western European Book of Daniel was heretical. Collins's text was familiar to Russian scribes, but nevertheless sufficiently alien and problematic to necessitate excision. In this case, then, the translation process led to the deliberate removal of whole sentences deemed inappropriate for religious reasons.

The translation process was also used to add information to a report. In the 1665 text on valerian root Collins covers the physical appearance, properties, methods of preparation and modes of consumption of the plant. ${ }^{74}$ In the Russian version of the document there is an additional section, introduced in the report as excerpts from the herbal with 520 chapters, an as-yet unidentified Russian-language herbal. As the text specifies that the origin of the additional articles is a Russian-language herbal, it is unlikely that Collins, who knew very little Russian, could have chosen those excerpts to accompany his report; they are more likely to have been chosen by a Russian-speaking member of the Apothecary Chancery staff, perhaps the scribe who prepared the final, Russian version of Collins's report. The articles from the herbal complement Collins's abstract description of the properties of the root by providing specific recipes for its use. Here, Russian scribes used their ability to change the text of a report to include extra material relevant to the topic.

Close examination of the translation stage in the Apothecary Chancery's reporting information technology reveals two significant points: the impact of translation upon the content of a report, and the respective roles of the spoken and written word. The Russian text of a report could substantially differ from the Latin original, often because

Laila Nordquist, and Ewa Teodorowicz-Hellman (Stockholm: Acta Universitatis Stockholmiensis, 2002), pp. 181-90.

73 David A. Frick, 'Sailing to Byzantium: Greek Texts and the Establishment of Authority in Early Modern Muscovy', Harvard Ukrainian Studies, 19 (1995), 138-57.

Mamonov, Materialy, 3, pp. 791-94. 
of deliberate changes to the text undertaken by the translator, who either added or removed elements. Translation was thus a form of editing, which could have a major influence on the final content of a report. Alongside these written reports, reports were also spoken aloud, then translated and transcribed, which process also affected the final form of the report. In the chancery system, the spoken word was a fundamental part of report creation, and so of the chancery system's form of information technology. The chancery system was a literate bureaucracy, but it also relied heavily upon the spoken word.

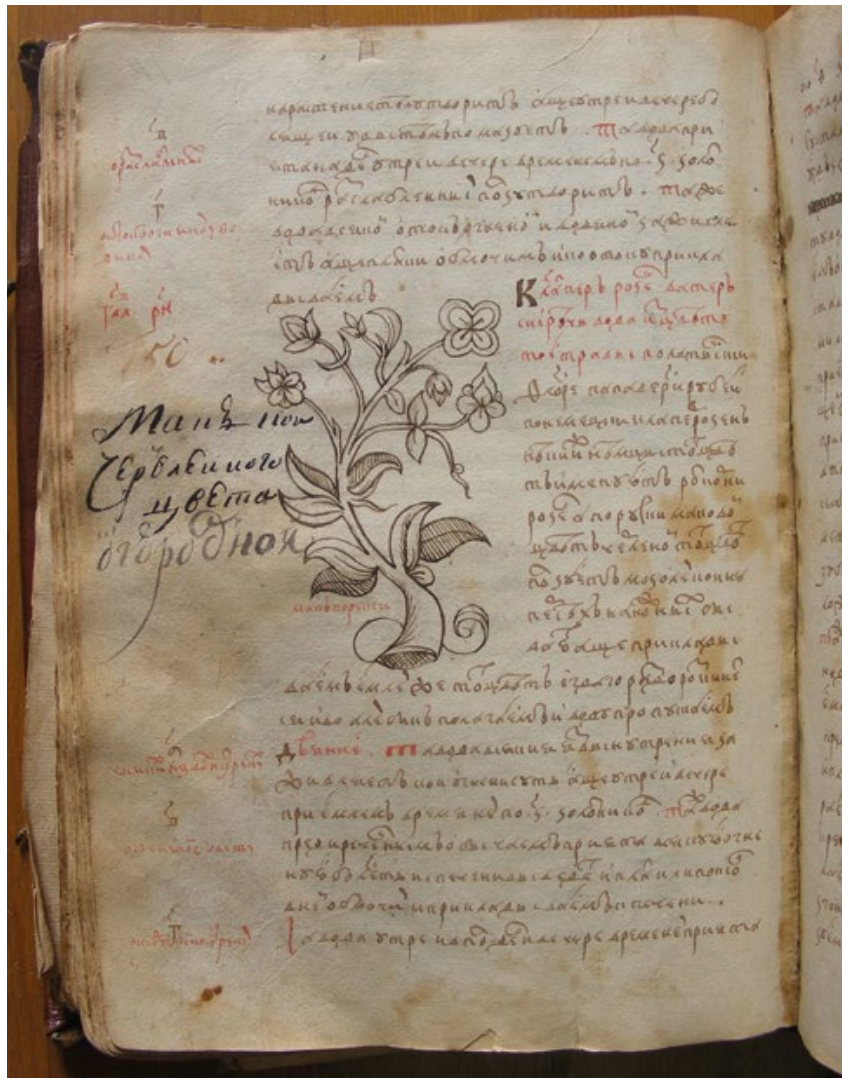

Figure 3. A herbal page (ca. seventeenth century). 


\section{Circulating Knowledge}

Once an Apothecary Chancery report had been written and translated, it was then circulated. In the case of the 1628 witchcraft trial with which we began, it was sent back to the Military Service Chancery bureaucrats overseeing the case, and possibly forwarded to the governor of Rzhev, under whose authority the arrest was initially made, and, for that matter, the governor of Toropets, the accused's home town, and the Archangel monastery in Ustiug Velikii, to which he was then sent. That report thus circulated not just within the Apothecary Chancery, or even between that department and the palace, but within the wider Muscovite administrative system. It is even possible that the accused himself, Loptunov, a peasant from a rural noble estate, and his master, Mikhail Polibin, who was losing a peasant, were also made aware of the contents of the report affecting Loptunov's fate. That would again expand the circulation of this report of expert Western European medical knowledge, out into Muscovite society. Following the further progress of Apothecary Chancery expert reports thus tells us about how these reports circulated, and whom in Muscovite society was the end user of this information technology.

Commonly, the end user of a report was the man who had ordered it: the Apothecary Chancery head, the head of the Military Service Chancery or other section of the administration, or indeed the tsar himself. In all the cases for which such information is available, the orderer was at least part of the circle to whom the report was distributed. The head of the Apothecary Chancery was a particularly vital part of this distribution system. As well as receiving his own reports, reports written by his department for others were sent to him first and, in the case of reports to be passed on to the tsar, he then personally delivered them. Such was the case in 1655, with the report on unicorn horn, and the 1679 autopsy of the boyar Vorotynskii. ${ }^{75}$ Similarly, when reports requested by other departments were completed, they were always first sent to the Apothecary Chancery director before being delivered

751655 report on purchase of unicorn horn: RGADA, coll. 143, descr. 2, file 147; Mamonov, Materialy, 2, p. 157; Mamonov, Materialy, 3, pp. 636-39. 1679 autopsy of Vorotynskii: Mamonov, Materialy, 4, p. 1304, pp. 1198-99. 
to the relevant chancery. Such was the case in 1679, for the autopsy of one of the Patriarch's grooms on behalf of the Land Chancery (Zemskii prikaz). ${ }^{76}$ The head of the Apothecary Chancery was thus a vital figure in circulating reports created by his department to a relevant audience.

Consuming a report did not necessarily mean reading it. We know from other sources that reports were commonly read to the tsar and his advisers. ${ }^{77}$ Far from all Russian nobles were functionally literate, so this was an efficient system for transmitting information. Leaving aside the literacy issue, there are reasons that the spoken word is particularly helpful in exchanging information. As pointed out by more than one colleague during the workshop from which this chapter emerged, academics regularly fly around the world to speak face-to-face, even though we could rather more easily send a text to each other to read. This circumstance is (hopefully) not a statement on the literacy of the academics involved, but rather reflects the special role the spoken word can play in knowledge exchange (the opportunity to exchange that knowledge in chic local restaurants is merely a pleasant by-product). There were also good reasons to use the spoken word to convey certain reports at the seventeenth-century Russian palace. The number of people holding a counsellor rank, and so who could advise the tsar, went from around thirty before 1645 , to approximately seventy in the latter part of the century. ${ }^{78}$ In reality, the tsar's council was often rather smaller, but he could still be in discussion with perhaps fifteen people..$^{79}$ Reading the report aloud to such a group would be a rather more efficient way of conveying the information than making and circulating anything from sixteen to seventy-one manuscript copies, or alternatively circulating a

76 Mamonov, Materialy, 4, pp. 1161-62.

77 Ingrid Maier and Wouter Pilger, 'Second-hand Translation for Tsar Aleksej Mixajovich-a Glimpse into the "Newspaper Workshop" at Posol'skij Prikaz', Russian Linguistics, 25 (2001), 209-42 (p. 215).

78 Marshall Poe, The Russian Elite in the Seventeenth Century, 2 vols (Helsinki: Finnish Academy of Sciences and Letters, 2004), 1, pp. 13-15; Poe, 'Tsar Aleksei Mikhailovich and the End of the Romanov Political Settlement', Russian Review, 62 (2003), 537-64; Robert O. Crummey, Aristocrats and Servitors: The Boyar Elite in Russia, 1613-89 (Princeton and Guildford: Princeton University Press, 1983), p. 88. See also HansJoachim Torke, 'Oligarchie in der Autocratie-Der Machtverfall Der Bojarenduma Im 17. Jahrhundert', Forschungen zur osteuropäischen Geschichte, 24 (1978), 179-201.

79 See P. V. Sedov, Zakat Moskovskogo tsarstva. Tsarskii dvor kontsa XVII veka (St Petersburg: Dmitrii Bulanin, 2008), pp. 13-19. 
smaller number of copies among that many people. In such situations, the spoken word was a more efficient way to communicate reports.

Apothecary Chancery reports were also made available to people outside the chancery system. When the department produced reports for witchcraft and medical malpractice trials, that report may well have been shown to the defendant, a person who often came from outside the chancery system. Indeed, in 1690, one of the defendants in a witchcraft and blasphemy case, Perfilii Rokhmaninov, a townsman (posadskii chelovek) from Galich, petitioned for the herbs found in his possession to examined by the Apothecary Chancery, asking that "those herbs be examined in the Apothecary [Chancery], and those herbs are not magical" ${ }^{80}$ The date of Rokhmaninov's request is significant: in the late seventeenth century, former and current Apothecary Chancery staff members were compiling self-help medical texts aimed at literate Russian audiences. ${ }^{81}$ This circumstance likely raised the profile of the Apothecary Chancery as a centre for medical expertise in Russian society, and this possibly motivated Rokhmaninov's request. Rokhmaninov knew that having an expert Apothecary Chancery report written for his case was a possibility, suggesting a significant knowledge of that department's reporting activities even outside the chancery system.

There is also some evidence that Apothecary Chancery reports may have been made available to foreign governments. We return here to the 1644 autopsy of Count Valdemar's retainer. ${ }^{82}$ The servitor in question died from a gunshot wound to the face, which wound he received in front of numerous witnesses. An autopsy would then seem to serve little purpose here, unless it was to send on to the Danes as part of an official response to the incident. In 1715 an autopsy report was written on the death of Charlotte Christine of Brunswick-Lüneburg, Tsarevich Alexei's wife. In this case, it is the language of the report that is odd: the file appears to be complete and undamaged, and yet it contains only a German and a Latin version of the autopsy, and no Russian text. ${ }^{83}$ Charlotte Christine was the sister-in-law of the Holy Roman Emperor

80 N. Ia. Novombergskii, Vrachebnoe stroenie v do-Petrovskoi Rusi (Tomsk: Parovaia tipolitografiia Sibirskogo tovarishchestva pechatnogo dela, 1907), p. 93.

81 See Griffin, 'In Search of an Audience'.

82 Mamonov, Materialy, 1, pp. 62-63.

83 RGADA, coll. 143, descr. 2, file 1635. 
Charles VI, whom Russia hoped to count as an ally in an expected war against the Ottomans. It is thus very possible that the report on her death was prepared primarily to send to Charles VI, in which case the languages of the report would make perfect sense. These two cases thus show that the chancery system's form of information technology could communicate information not only outside the chancery system, but potentially even outside of Russia.

The readership of Apothecary Chancery reports highlights vital aspects of knowledge circulation in the Russian context. Firstly, it speaks to the role of the Apothecary Chancery within the chancery system, and indeed our ideas of how the chanceries worked as a system, rather than merely a group of institutions. The Apothecary Chancery is commonly viewed as a palace instrument, as indeed it often functioned. But devoting attention to the flow of reports reveals the broader networks in which the Apothecary Chancery was involved, linking together the wider Muscovite administration beyond the walls of the Kremlin, some parts of Russian society, and even, potentially, other governments. Secondly, looking at circulation shows us how things circulated: the spoken word was as important here as the written word. Muscovites were as likely to find out the contents of a report by having it read to them as by reading it themselves. The Apothecary Chancery's reporting system shows substantial circulation of medical knowledge, circulation that was achieved by the purposeful use of both manuscript and the spoken word.

\section{Storing Knowledge}

The final stage of all Apothecary Chancery documents was storage. In a sense though, this was a stage long in preparation through the very processes of creating the document. As the orders, reports, and responses circulated through the system, they gained a manuscript form of metadata, data about data. When the order for a report on Loptunov's root reached the Apothecary Chancery in 1628, it did not arrive merely as an order, but was accompanied by a précis of the case up until the moment the order arrived at the department. That précis was then used to form a file in the Apothecary Chancery, along with a copy of the report; similarly, a copy of the report was also sent back to the Military 
Service Chancery to be included in their file. In many cases, we have both draft versions of a document (chernovik) and the final, clean version (belovik). The existence of drafts and clean copies reflects the great care taken in creating these documents. In the seventeenth century Russia still imported much of its paper. Nevertheless, even the most mundane of documents was drafted and redrafted before a final version of the document could be approved, showing the meticulous construction of Muscovite files.

These files were stolbtsy, scrolls, which were used for the majority of Russian administrative documents until around the 1690s. ${ }^{84}$ This was a security measure: as each document was added to a file, it would be glued to its predecessor and an elaborate signature made across the back of the join, so that original documents could not be removed, nor fakes introduced, without someone noticing. One reason for such care was to ensure that one could refer back to the documents accurately. We have evidence that the Apothecary Chancery did just that on a number of occasions: several prescriptions contain a note that either they were created on the basis of an earlier prescription, or that a prescription was repeated later. ${ }^{85}$ I have not come across any such notations in the reports discussed here, but the careful recording and storage of these documents indicates that reports, like the Apothecary Chancery prescriptions, were kept for the possibility of such reference.

The knowledge created by the Apothecary Chancery was directed towards particular, limited, problems and questions, but it was not transitory. On the contrary, like all chancery documents, it was created in a secure and traceable manner, both to aid its real-time use and to help its storage for potential later reference. Direct evidence of such references only exists for prescriptions, not reports. Nevertheless, it is important that this was a possibility that was anticipated and allowed for by the system itself. The Apothecary Chancery information technology ensured that data, once created, could be retrieved.

84 Shmidt and Kniaz'kov, Dokumenty, pp. 21-27.

85 See for example the 1674 order to repeat a previous prescription: RGADA, coll. 143, descr. 2, file 1093, fol. 45. 1666 prescription for I. D. Miloslavskii from earlier prescription by Dr Engelhardt: RGADA, coll. 143, descr. 2, file 743, fol. 46. 


\section{Conclusion}

We began this chapter in 1628, when the arrest of a man possessing a peculiar root set in action the massive bureaucracy of the Muscovite administration, allowing us to follow the process by which expert reports were ordered, created, translated, circulated, and stored. Examining these processes reveals the nature and role of information technology and knowledge exchange in seventeenth-century Russia, and also gives us a specific case of an early modern information technology to help us to examine that concept more closely. The Apothecary Chancery reporting system allowed the creation of orders for specific pieces of knowledge, the creation of knowledge to that particular end, the transformation (translation) of that knowledge into a form fit for usage in context, the circulation of that knowledge around a system, and the storage of that knowledge for potential later retrieval. This was an information technology.

Looking at the Apothecary Chancery reporting system as a form of information technology gives us a new view on that department, the chancery system as a whole, and indeed the running of the seventeenthcentury Russian state. The chancery system has often been studied by dividing it up, with the Apothecary Chancery seen as limited to palace medicine. Looking at the report circulation, it is clear that, while the Apothecary Chancery did indeed serve the court, it fulfilled a number of functions beyond merely treating the sick, and also regularly provided expert knowledge to a number of other departments. Tracing such interactions shows the chancery system to be dynamic and interactive, with the Apothecary Chancery being far more than simply a dispensary for the Muscovite elite.

Most interesting is how this information technology functioned. The chancery system was a bastion of literacy in a culture where literacy was not always highly valued. Literacy and documentation played a substantial role in the encoding and storage of Apothecary Chancery knowledge. Printed texts likely played a part as reference texts in the Apothecary Chancery library, but it was the chancery manuscript scrolls which took centre stage. Orality was also a major element in this system. Orders were given orally; some reports were produced, and translated, orally before being written down; and reports were consumed orally. 
Here, the spoken word was not subordinate to the written word, nor used when one could not read or write. It was used alongside writing, and even in preference to it, because orality has its own utility. In the Apothecary Chancery's early modern information technology, manuscripts and the spoken word were the key mediums; this argues for the inclusion of oral communication in interaction with written, and printed, communication in histories of early modern information technologies. 



\section{Selected Further Reading}

Alef, Gustave, 'The Origin and Early Development of the Muscovite Postal Service', Jahrbücher für Geschichte Osteuropas, New Series, 15. 1 (March 1967), $1-15$.

Alekseeva, M. A., Iz istorii russkoi graviury XVII-nachala XIX v. (Moscow and St Petersburg: Al'ians Arkheo, 2013).

Anisimov, Evgenii V., Podatnaia reforma Petra I (Leningrad: Nauka, 1982).

Antonov, P. A., 'Vyveski', Neva, 4 (1986), 183-88.

Bagrow, Leo, A History of the Cartography of Russia up to 1600, and A History of Russian Cartography up to 1800, both ed. by Henry W. Castner (Wolfe Island, ON: The Walker Press, 1975).

Bauer, Volker, and Holger Böning, eds., Die Entstehung des Zeitungswesens im 17. Jahrhundert: Ein neues Medium und seine Folgen für das Kommunikationssystem der Frühen Neuzeit (Bremen: Edition Lumière, 2011).

Becker, Peter, “"Kaiser Josephs Schreibmaschine”: Ansätze zur Rationalisierung der Verwaltung im aufgeklärten Absolutismus', Jahrbuch für europäische Verwaltungsgeschichte, 12 (2000), 223-54.

Beliaev, L. A., ed., Russkoe srednevekovoe nadgrobie, XIII-XVII veka: materialy $k$ svodu. Vypusk 1 (Moscow: Nauka, 2006).

Behringer, Wolfgang, Im Zeichen des Merkur. Reichspost und Kommunikationsrevolution in der Frühen Neuzeit. Veröffentlichungen des Max-Planck-Instituts für Geschichte, Bd. 189 (Göttingen: Vandenhoeck \& Ruprecht, 2003).

Berkov, P. N., Istoriia russkoi zhurnalistiki XVIII veka (Moscow: Izdatel'stvo Akademii nauk SSSR, 1952).

Blair, Ann M., Too Much to Know: Managing Scholarly Information before the Modern Age (New Haven: Yale University Press, 2010). 
Bogoslovskii, Mikhail, Oblastnaia reforma Petra Velikogo. Provintsiia 1719-27 (Moscow: Universitetskaia tipografiia, 1902).

Bondarenko, A. F., Istoriia kolokolov v Rossii XI-XVII vv. (Moscow: Russkaia panorama, 2012).

Borodkin, L. I., and Iu. Petrov, eds., Ekonomicheskaia istoriia. Ezhegodnik 2013 (Moscow: Rossiiskaia politicheskaia entsiklopediia, 2014), pp. 89-127.

Brown, Peter B., 'How Muscovy Governed: Seventeenth-Century Russian Central Administration', Russian History, 36 (2009), 459-529, https://doi.org/ 10.1163/009428809x12536994047659

Buckler, Julie, Mapping St Petersburg: Imperial Text and Cityshape (Princeton: Princeton University Press, 2005).

Burmistrova, L. P., Provintsial'naia gazeta v epokhu russkikh prosvetitelei (Gubernskie vedomosti Povolzh'ia i Urala 1840-1850 gg.) (Kazan: Izdatel'stvo Kazanskogo universiteta, 1985).

Chechulin, N. D., Ocherki po istorii russkikh finansov v tsarstvovanie Ekateriny II (St Petersburg: Senatskaia tipografiia, 1906).

Chernyshev, V. A., Konnye povozki i ekipazhi v Rossii X-XIX vekov (St Petersburg: Fort, 2007).

Collins, Daniel, Reanimated Voices. Speech Reporting in a Historical-Pragmatic Perspective (Amsterdam and Philadelphia: John Benjamins, 2001), https:// doi.org/10.1075/pbns.85

Cracraft, James, The Petrine Revolution in Russian Imagery (Chicago and London: University of Chicago Press, 1997).

Cross, Anthony, By the Banks of the Neva: Chapters from the Lives and Careers of the British in Eighteenth-Century Russia (Cambridge: Cambridge University Press, 1997).

Dickinson, Sara, Breaking Ground: Travel and National Culture in Russia from Peter I to the Era of Pushkin (Amsterdam: Rodopi, 2006).

Distribuendi, F., Vzgliad na moskovskie vyveski (Moscow: I. Smirnov, 1836).

Dixon, Simon, The Modernisation of Russia, 1676-1825 (Cambridge: Cambridge University Press, 1999).

Dooley, Brendan, ed., The Dissemination of News and the Emergence of Contemporaneity in Early Modern Europe (Farnham, Surrey and Burlington, VT: Ashgate Publishing, 2010).

Droste, Heiko, ed., Connecting the Baltic Area: The Swedish Postal System in the Seventeenth Century (Stockholm: Södertörns högskola, 2011).

Dumschat, Sabine, Ausländischer Mediziner im Moskauer Rußland (Stuttgart: Franz Steiner Verlag, 2006). 
Eisenstein, Elizabeth L., The Printing Press as an Agent of Change (New York and Cambridge: Cambridge University Press, 1979).

Esin, B. I., and I. V. Kuznetsov, Trista let otechestvennoi zhurnalistiki (1702-2002) (Moscow: Izdatel'stvo Moskovskogo universiteta, 2002).

Franklin, Simon, 'Mapping the Graphosphere: Cultures of Writing in Early 19thCentury Russia (and Before)', Kritika, 12. 3 (Summer 2011), 531-60, https:// doi.org/10.1353/kri.2011.0036

Franklin, Simon, 'Printing and Social Control in Russia 2: Decrees', Russian History, 38 (2011), 467-92, https://doi.org/10.1163/187633111x594560

Garrioch, David, 'House Names, Shop Signs and Social Organization in West European Cities, c. 1500-1900', Urban History, 21 (1994), 20-48.

Gatrell, Peter, 'Economic Culture, Economic Policy and Economic Growth in Russia, 1861-1914', Cahiers du Monde Russe, 1 (1995), 37-52.

Glinternik, Eleonora, Reklama v Rossii XVIII-pervoi poloviny XX veka (St Petersburg: Avrora, 2007).

Goldenberg, L. A., 'Russian Cartography to ca. 1700', in The History of Cartography, vol. 3, pt. 2, Cartography in the European Renaissance (Chicago: University of Chicago Press, 2007), http://www.press.uchicago.edu/books/ HOC/HOC_V3_Pt2/HOC_VOLUME3_Part2_chapter62.pdf

Golubinskii, A. A., 'Stepan Khrulev: Sud'ba zemlemera', in Rus', Rossiia, Srednevekov'e i Novoe vremia, vypusk III, Tret'i chteniia pamiati akademika RAN L.V. Milova (Moscow: Orgkomitet Chtenii pamiati akademika RAN L. V. Milova, 2013), pp. 404-10.

Gnucheva, V. F., Geograficheskii departament Akademii nauk XVIII veka (Moscow: Izd-vo AN SSSR, 1946).

Griesse, Malte, ed., From Mutual Observation to Propaganda War. Premodern Revolts in Their Transnational Representations (Bielefeld: Transcript Verlag, 2014), https://doi.org/10.14361/transcript.9783839426425

Gromova, L. P., ed., Istoriia russkoi zhurnalistiki XVIII-XIX vekov (St. Petersburg: Izdatel'stvo Sankt-Peterburgskogo universiteta, 2003).

Gurliand, I. Ia., Iamskaia gon'ba v moskovskom gosudarstve do kontsa XVII veka (Iaroslavl: Tipografiia Gubernskogo Pravleniia, 1900).

Harms, Wolfgang, Das illustrierte Flugblatt in der Kultur der Frühen Neuzeit: Wolfenbüttler Arbeitsgespräch 1997 (Frankfurt am Main: Peter Lang, 1998).

Hartley, Janet, Russia, 1762-1815: Military Power, the State and the People (Westport: Praeger, 2008).

Herberstein, Sigmund Freiherr von, Notes Upon Russia, 2 vols, Elibron Classics Reprint of the 1852 publication by the Hakluyt Society (Adamant Media, 2005), https://archive.org/details/notesuponrussiab02herbuoft 
Hobart, Michael E., and Zachary S. Schiffman, Information Ages: Literacy, Numeracy, and the Computer Revolution (Baltimore: Johns Hopkins University Press, 2000).

Il'iushina, T. V., 'Ot bussoli do astroliabii', Nauka v Rossii, 3 (2007), 97-101.

Jones, Robert E., Provincial Development in Russia: Catherine II and Jacob Sievers (New Brunswick: Rutgers University Press, 1984).

Kahan, Arcadius, The Plow, the Hammer and the Knout: An Economic History of Eighteenth-Century Russia (Chicago: University of Chicago Press, 1985).

Kationov, O. N., Moskovsko-Sibirskii trakt i ego zhiteli v XVII-XIX vv. (Novosibirsk: NGPU, 2004).

Keuning, Johannes, 'Nicolaas Witsen as a Cartographer', Imago Mundi, 11 (1954), 95-110, https://doi.org/10.1080/03085695408592063

Kiselev, Mikhail, 'State Metallurgy Factories and Direct Taxes in the Urals, 170050: Paths to State Building in Early Modern Russia', Kritika: Explorations in Russian and Eurasian History, 16. 1(Winter 2015), 7-36, https://doi.org/10.1353/ kri.2015.0012

Kivelson, Valerie, Cartographies of Tsardom: Maps and their Meanings in Seventeenth Century Russia (Ithaca, NY: Cornell University Press, 2007).

In Russian: Kivel'son, Valerii, Kartografii tsarstva: Zemlia i ee znacheniia $v$ Rossii XVII veka (Moscow: Novoe literaturnoe obozrenie, 2012).

Kivelson, Valerie, Desperate Magic: The Moral Economy of Witchcraft in Seventeenthcentury Russia (Ithaca and London: Cornell University Press, 2013), https:// doi.org/10.7591/9780801469381

Kollmann, Nancy Shields, The Russian Empire 1450-1801 (Oxford: Oxford University Press, 2017), https://doi.org/10.1093/acprof:o so/9780199280513.001.0001

Kochegarov, Kirill A., Rech' Pospolitaia i Rossiia v 1680-1686 godakh. Zakliuchenie dogovora o Vechnom mire (Moskva: INDRIK, 2008).

Kotel'nikova, I., 'Introduction', in The Panorama of Nevsky Prospect (Leningrad: Aurora Art, 1974), pp. 7-78.

Kotilaine, Jarmo, and Marshall Poe, eds., Modernizing Muscovy: Reform and Social Change in Seventeenth Century Russia (London and New York: Routledge Curzon, 2004), https://doi.org/10.4324/9780203507032

Kozlovskii, Ivan P., Pervye pochty i pervye pochtmeistery $v$ moskovskom gosudarstve, 2 vols. (Warsaw: Tip. Varshavskogo uchebnogo okruga, 1913).

Kudriavtsev, A. S., Ocherki istorii dorozhnogo stroitel'stva v SSSR: Dooktiabr'skii period, 2 vols (Moscow: Dorizdat, 1951).

Kulomzin A. N., 'Finansovye documenty tsarstvovaniia Imperatritsy Ekateriny II', Sbornik Rossiiskogo Imperatorskogo Obshchestva, vol. 28 (St Petersburg: tip. V. Bezobrazova i Komp., 1880). 
Küng, Enn, 'Postal Relations between Riga and Moscow in the Second Half of the 17th Century', Past. Special Issue on the History of Estonia (Tartu-Tallinn: National Archives, 2009), 59-81.

Kusov, V. S., Chertezhi zemli russkoi XVI-XVII vv. (Moscow: Russkii mir, 1993).

Kusov, V. S., Izmerenie zemli: Istoriia geodezicheskikh instrumentov (Moscow: Dizain. Informatsiia. Kartografiia, 2009).

Larwood, Jacob, and John Camden Hotten, The History of Signboards from the Earliest Times to the Present Day (London: John Camden Hotten, 1867).

Le Donne, John P., Absolutism and Ruling Class. The Formation of the Russian Political Order, 1700-1825 (Oxford: Oxford University Press, 1991).

Lincoln, W. Bruce, Nicholas I: Emperor and Autocrat of All the Russias (Bloomington: Indiana University Press, 1978).

Liseitsev, D. V., N. M. Rogozhin, and Iu. M. Eskin, Prikazy Moskovskogo gosudarstva XVI-XVII vv. Slovar'-spravochnik (Moscow and St Petersburg: Tsentr gumanitarnikh initsiativ, 2015).

Lyubichankovski, Sergei V., 'The State of Power in the Late Russian Empire: The English-American Historiography of the Second Half of the XXth-Early XXIst Centuries', Proceedings of the Samara Scientific Center of the Russian Academy of Sciences, 2 (2007), 342-47.

Maier, Ingrid, 'Newspaper Translations in Seventeenth-Century Muscovy. About the Sources, Topics and Periodicity of Kuranty "Made in Stockholm" (1649)', in Explorare necesse est. Hyllningsskrift till Barbro Nilsson, Acta Universitatis Stockholmensis, Stockholm Slavic Studies, vol. 28 (Stockholm: Almqvist \& Wiksell, 2002), 181-90.

Maier, Ingrid, and Wouter Pilger, 'Polnische Fabelzeitung über Sabbatai Zwi, übersetzt für den russischen Zaren', Zeitschrift für slavische Philologie, 62. 1 (2003), 1-39.

Mamonov, N. E., Materialy dlia istorii meditsiny $v$ Rossii, 4 vols (St Petersburg: M. M. Stasiulevich, 1881).

Man'kov, A. G., ed., Inostrannye izvestiia o vosstanii Stepana Razina. Materialy $i$ issledovaniia (Leningrad: Nauka, 1975).

Marker, Gary, Publishing, Printing, and the Origins of Intellectual Life in Russia, 1700-1800 (Princeton: Princeton University Press, 1985).

Marks, Stephen G., The Information Nexus: Global Capitalism from the Renaissance to the Present (Cambridge: Cambridge University Press, 2016), https://doi. org/10.1017/cbo9781316258170

Martin, Alexander M., Enlightened Metropolis: Constructing Imperial Moscow, 1762-1855 (Oxford: Oxford University Press, 2013), https://doi.org/10.1093/ acprof:oso/9780199605781.001.0001 
Martin, Welke, 'Rußland in der deutschen Publizistik des 17. Jahrhunderts (1613-1689)', Forschungen zur osteuropäischen Geschichte, 23 (1976), 105-276.

McConnell, Allen, Tsar Alexander I: Paternalistic Reformer (New York: Crowell, 1970).

Mironov, Boris N., Rossiiskaia imperiia: ot traditsii k modernu, vol. 2 (St Petersburg: Dmitrii Bulanin, 2014).

Ogloblin, Nikolai, 'Voevodskie vestovye otpiski XVII v. kak material po istorii Malorossii', Kievskaia starina, 12 (1885), 365-416.

Orlova, Galina, 'Biurokraticheskaia real'nost', Obshchestvennye nauki $i$ sovremennost', 6 (1999), 96-106.

Petrucci, Armando, Public Lettering. Script, Power, and Culture, trans. by Linda Lappin (London and Chicago: Chicago University Press, 1993).

Petrukhintsev, N. N., ‘Tsarstvovanie Anny Ioannovny: problemy formirovaniia vnutripoliticheskogo kursa (1730-1740)' (Dokt. dissertation, Moskovskii gosudarstvennyi universitet, 2001).

Pettegree, Andrew, The Invention of News: How the World Came to Know about Itself (New Haven and London: Yale University Press, 2014).

Pisar'kova, Ludmila F., 'Rossiiskaia biurokratiia v epohu Petra I', Otechestvennaia istoriia, 1 (2004), 18-41.

Postnikov, A. V., Karty zemel' rossiiskikh: ocherk istorii geograficheskogo izucheniia $i$ kartografirovaniia nashego otechestva (Moscow: Nash dom and L'Âge d'Homme, 1996). In English: Postnikov, A. V., Russia in Maps: A History of the Geographical Study and Cartography of the Country (Moscow: Nash dom and L'Âge d'Homme, 1996).

Postnikov, Alexey and Marvin Falk, Exploring and Mapping Alaska: The Russian America Era, 1741-1867, trans. by Lydia Black (Fairbanks: University of Alaska Press, [2015]).

Povelikhina, Alla, and Yevgeny Kovtun, Russian Painted Shop Signs and AvantGarde Artists, trans. by Thomas Crane and Margarita Latsinova (Leningrad: Aurora Art, 1991).

Presniakov, A. E., Emperor Nicholas I of Russia: The Apogee of Autocracy, 1825-1855, ed. and trans. J. C. Zacek (Gulf Breeze: Academic International Press, 1974).

Redin, D. A., Administrativnye struktury i biurokratiia Urala v epokhu petrovskikh reform (zapadnye uezdy Sibirskoi gubernii v 1711-1727 gg.) (Ekaterinburg: Volot, 2007).

Remezov, S. U., Chertezhnaia kniga Sibiri, sostavlennaia tobol'skim synom boiarskim Semenom Remezovym v 1701 godu, ed. by A. A. Drazhniuk, et al., 2 vols. (Moscow: PKO “Kartografiia”, 2003).

Remezov, S. U., Khorograficheskaia kniga Sibiri. MS Russ 72 (6). Houghton Library, Harvard University, Cambridge, MA, ff. 5v-6, http://pds.lib.harvard.edu/ pds/view/18273155? $=10 \&$ imagesize $=1200 \&$ p2Res $=.25 \&$ print Thumbnails $=$ no 
Remnek, Miranda, ed., The Space of the Book: Print Culture in the Russian Social Imagination (Toronto: University of Toronto Press, 2010), https://doi. org/10.3138/9781442686441

Rey, Marie-Pierre, Alexander I: The Tsar Who Defeated Napoleon (DeKalb: Northern Illinois University Press, 2012).

Riasanovsky, N. V., A Parting of Ways: Government and the Educated Public in Russia, 1801-1855 (Oxford: Clarendon Press, 1976).

Riazantsev, I. V., Skul'ptura v Rossii XVIII-nachala XIX veka (Moscow: Zhiraf, 2003).

Ruban, Anatolij and Ekaterina Basargina, eds., Russische klassische Altertumswissenschaft in der Zeitschrift des Ministeriums für Volksaufklärung (St Petersburg: Bibliotheca Classica Petropolitana and Nestor-Verlag, 2012).

Sadovnikov, V. S., Panorama of Nevsky Prospect: from the Collection of the Russian Museum, ed. by Nataliia Shtrimer (Leningrad: Aurora Art Publishers, 1993).

Sazikov, A. V., and T. V. Vinogradova, Naruzhnaia reklama Moskvy. Istoriia, tipologiia, dokumenty (Moscow: Russkii Mir, 2013).

Sedov, P. V., Zakat Moskovskogo tsarstva. Tsarskii dvor kontsa XVII veka (St Petersburg: Dmitrii Bulanin, 2008).

Shamin, Stepan M., Kuranty XVII stoletiia. Evropeiskaia pressa v Rossii $i$ vozniknoveniia russkoi periodicheskoi pechati (Moscow and St Petersburg: Al'ians-Arkheo, 2011).

Shevtsov, V. V., “Tomskie gubernskie vedomosti" (1857-1917 gg.) v sotsiokul'turnom $i$ informatsionnom prostranstve sibiri (Tomsk: Tomskii gosudarstvennyi universitet, 2012).

Silverstein, Adam J., Postal Systems in the Pre-Modern Islamic World (Cambridge: Cambridge University Press, 2007), https://doi.org/10.1017/ CBO9780511497520

Smith-Peter, Susan, 'The Russian Provincial Newspaper and Its Public, 17881864', Carl Beck Papers 1908 (2008), https://doi.org/10.5195/cbp.2008.145

Tiukhmeneva, E. A., Iskusstvo triumfal'nykh vrat v Rossii pervoi poloviny XVIII veka. Problemy panegiricheskogo napravleniia (Moscow: Progress-Traditsiia, 2005).

Uchenova, V. V. and N. V. Starykh, Istoriia reklamy (Moscow: Smysl, 1994).

Velychenko Stephen, 'The Size of the Imperial Russian Bureaucracy and Army in Comparative Perspective', Jahrbücher für Geschichte Osteuropas, New Series, 49.3 (2001), 346-62.

Vigilev, A. N., Istoriia otechestvennoi pochty, 2nd ed. (Moscow: Radio i sviaz', 1990).

Waugh, Daniel C., 'The Best Connected Man in Muscovy? Patrick Gordon's Evidence Regarding Communications in Muscovy in the 17th Century', Journal of Irish and Scottish Studies, 7.2 (2014 [2015]), 61-124. 
Waugh, Daniel C., The Great Turkes Defiance: On the History of the Apocryphal Correspondence of the Ottoman Sultan in Its Muscovite and Russian Variants, with a foreword by Dmitrii Sergeevich Likhachev (Columbus: Slavica Publishers, 1978).

Waugh, Daniel C. and Ingrid Maier, 'How Well Was Muscovy Connected with the World?', in Imperienvergleich: Beispiele und Anätze aus osteuropäischer Perspektive. Festschrift für Andreas Kappeler, ed. by Guido Hausmann and Angela Rustemeyer, Forschungen zur osteuropäischen Geschichte, Bd. 75 (Wiesbaden: Harrassowitz, 2009), 17-38.

Weller, Toni, ed., Information History in the Modern World. Histories of the Information Age (Basingstoke: Palgrave Macmillan, 2011), https://doi. org/10.1533/9781780631318

West, Sally, I Shop in Moscow: Advertising and the Creation of Consumer Culture in Late Tsarist Russia (DeKalb: Northern Illinois University Press, 2011).

Whittaker, C. H., The Origins of Modern Russian Education: An Intellectual Biography of Count Sergei Uvarov, 1786-1855 (DeKalb: Northern Illinois University Press, 1984).

Witzenrath, Christoph, 'Literacy and Orality in the Eurasian Frontier: Imperial Culture and Space in Seventeenth-Century Siberia and Russia', Slavonic and East European Review, 87.1 (2009), 53-77.

Wortman, Richard S., Scenarios of Power: Myth and Ceremony in Russian Monarchy from Peter the Great to the Death of Nicholas I (Princeton: Princeton University Press, 1995).

Zakharov, V. N., Y. A. Petrov and M. K. Shatsillo, Istoriia nalogov v Rossii. IXnachalo XX v. (Moscow: ROSSPEN, 2006). 


\section{List of Figures}

\section{Early Mapping: The Tsardom in Manuscript}

1. Willem Janszoon Blaeu, Tabula Russiae (1635). Map and inset of the city of Moscow based on Isaac Massa's maps. Image in the public domain. Wikimedia, https://commons.wikimedia. org/wiki/File:Willem_Janszoon_Blaeu._Tabula_Russiae_ex_ autographo,_quod_delineandum_curavit_Foedor_filius_Tzaris_ Borois_desumta._MDCXIIII.jpg

2. Isaac Massa, Russiæ, vulgo Moscovia, Pars Australis [The Southern part of Russia, aka Muscovy], from Theatrum Orbis Terrarum, sive Atlas Novus in quo Tabulæ et Descriptiones Omnium Regionum, ed. by Willem and Joan Blaeu (1645), from the collection of the University of California. Image in the public domain. Wikimedia, https://commons.wikimedia.org/wiki/File:Blaeu_1645_-_Russiæ_ vulgo_Moscovia_pars_australis.jpg

3. Isaac Massa, Caerte van't Noorderste Russen, Samojeden, ende Tingoesen Landt [Map of the Northern-most Russian, Samoyed, and Tungusic land, as copied from the Russians] (1610), from $A$ Short History of the Beginnings and Origins of These Present Wars in Moscow under the Reign of Various Sovereigns down to the Year 1610 by Isaac Massa, translated and with an introduction by G.[eorge] Edward Orchard, Toronto [u.a.], 1994. Image in the public domain. Wikimedia, https://commons.wikimedia.org/wiki/File: Massa_-_Caerte_van't_Noorderste_Russen,_Samojeden,_ende_ Tingoesen_Landt.jpg

4. Map of Moscovia, Sigismund von Herberstein (1549). Image in the public domain. Wikimedia, https://commons.wikimedia.org/ wiki/File:Herberstein-Moscovia.jpg

5. Drawing of the Lands of the River Solonitsa (1533). Reproduced from A. V. Postnikov, Russia in Maps: A History of the Geographical Study and Cartography of the Country (Moscow: Nash dom and L'Âge d'Homme, 1996). Image (c) RGADA, all rights reserved. 
6. Map of Aleksin (1671). RGADA, coll. 1209, Aleksin stlb. 31 494, fol. 115. Image (c) RGADA, all rights reserved.

7. Signatures on obverse of a map of lands along the Kamenka and the Urshma rivers in Suzdal Province. RGADA, coll. 1209, Suzdal' stlb. 27955, ch. 1, 1. 73b. Image @ RGADA, all rights reserved.

8. Map of the lands along the river Lakhost near the village of Tolstikova in Suzdal Province. RGADA, coll. 1209, Suzdal' stlb. 28043, Ch. 1, fol. 142. Image (C) RGADA, all rights reserved.

9. Map of the land along the river Sem Kolodezei in Iurev Polskoi Province, 1670-72. "The ploughed land of the uninhabited arable field Tiapkova". RGADA, coll. 1209, Iur'ev Pol'skoi, stlb. 34253, Ch. 1, fol. 132. Image (C) RGADA, all rights reserved.

10. Borovsk, RGADA, coll. 192, descr. 1, Kaluzhskaia guberniia, no. 1. Image (C) RGADA, all rights reserved.

11. Borovsk, satellite view from Google Maps (2017). Imagery (C) DigitalGlobe, Map data (c) Google, all rights reserved.

12. Martin Waldseemüller, Universalis cosmographia (1507), detail. Image in the public domain. Library of Congress, http://hdl.loc. gov/loc.gmd/g3200.ct000725C

13. S. U. Remezov's copy of the Godunov map of 1666-67, from his Chorographic Sketch Book. Image in the public domain. Houghton Library, Harvard University (Semen Ul'ianovich Remezov, Khorograficheskaia kniga [Chorographic Sketch-book of Siberia]. MS Russ 72 (6).).

14. Kamchatka. Map of Kamchatka included in S. U. Remezov's Working Sketch Book. Image in the public domain. Russian National Library, St Petersburg (Ermitazhnoe sobranie, no. 237, Sluzhebnaia chertezhnaia kniga Remezova, fol. 102v.).

15. S. U. Remezov, Map of All Siberia. Image in the public domain. Houghton Library, Harvard University (Bagrow Collection, MS Russ 72 (3).).

16. Map of a segment of the Tura River, from S. U. Remezov's Working Sketch Book. Image in the public domain. Houghton Library, Harvard University (Semen Ul'ianovich Remezov, Khorograficheskaia kniga [Chorographic Sketch-book of Siberia]. MS Russ 72 (6), Ch. 25, f. 48.). 


\section{New Technology and the Mapping of Empire: The Adoption of the Astrolabe}

1. Unknown artist. Plan of 1699 of the environs of Kolomna. (1799), Fragment, RGADA, coll. 1209, descr. 77, columns Kolomna, file 25186, fol. 43-44. Image (C) Aleksei Golubinskii, CC BY-NC 4.0.

2. Franciscus Fiebig/Franziskus Viebig. A universal astrolabe (semicircumferentor) with compass. (Middle of the seventeenth century). From Rossiia $i$ Gollandia: prostranstvo vzaimodeistviia. XVI-pervaia tret' XIX veka (Moscow: Kuchkovo pole, 2013), p. 311. Image in the public domain.

3-1 Depiction of an astrolabe (circumferentor) on the Plan of the city of Tver with its villages. Unknown artist (last quarter of the eighteenth century), RGADA, coll. 1356, descr. 1, file 6057. Image (C) Aleksei Golubinskii, CC BY-NC 4.0.

3-2 Depiction of an astrolabe (circumferentor) on the Plan of the city of Vesegonsk with its villages. Unknown artist (last quarter of the eighteenth century), RGADA, coll. 1356, descr. 1, file 6027. Image (C) Aleksei Golubinskii, CC BY-NC 4.0.

3-3 Depiction of an astrolabe (circumferentor) on the Plan of Tver Province. Unknown artist (last quarter of the eighteenth century), RGADA, coll. 1356, descr. 1, file 5949. Image @ Aleksei Golubinskii, CC BY-NC 4.0.

4. The Surveying Process. Fragment from the Map of Iaroslavl Province. Unknown artist (last quarter of the eighteenth century), RGADA. coll. 1356, descr. 1, file 6735. Image (C) Aleksei Golubinskii, CC BY-NC 4.0.

5. Unknown artist. Cercle, demicercle et cercle avec une rose de boussole d'arpenteur. From Recueil de planches sur les sciences, les arts libéraux et les arts méchaniques avec leur explications, vol. 1. (1765-72), Neuchâtel, 1779. Image in the public domain.

6. Fragment from the Plan of the city of Klin with its villages. Unknown artist (last quarter of the eighteenth century), RGADA, coll. 1356, descr. 1, file 2463. Image Image (C) Aleksei Golubinskii, CC BY-NC 4.0 . 


\section{How was Western Europe Informed about Muscovy? The Razin Rebellion in Focus}

1. An (invented) portrait of a turbaned Razin with a marshal's baton in his right hand from a German-language pamphlet (1671). The Royal Library, Copenhagen. Photo by Ingrid Maier, public domain.

2. Coloured drawing of Razin's execution (originally from Moscow), 1671, 400 x $310 \mathrm{~mm}$. The Swedish State Archives, Stockholm. Photo by Ingrid Maier, public domain.

3. Folding plate, printed in London (1672). The British Library.

Photo by Daniel C. Waugh, public domain.

\section{Bureaucracy and Knowledge Creation: The Apothecary Chancery}

1. The Apothecary Chancery today (2015). Photo by Clare Griffin, CC BY-NC 4.0.

2. An illuminated page from Josephus's Antiquities of the Jews, Brother Maciej and Master of the Lady with Unicorn (1466). From the collection of the National Library of Poland. Image in the public domain. Wikimedia, https://en.wikipedia.org/wiki/File:Josephus_ Antiquitates_Iudaice.jpg

3. Herbal Page ( $c a$. seventeenth century). The Library of the Russian Academy of Sciences, coll. 17, descr. 4, file 12. Photo by Clare Griffin, CC BY-NC 4.0.

\section{Communication and Official Enlightenment: The Journal of the Ministry of Public Education, 1834-1855}

1. V.A. Golike, Portrait of Count S. S. Uvarov (1833). Image in the public 320 domain. Wikimedia, https://commons.wikimedia.org/wiki/File: Golike_Vasily_Portrait_of_Count_Sergey_Uvarov_(1833).jpg 


\section{Experiencing Information: An Early Nineteenth-Century Stroll Along Nevskii Prospekt}

1. View of Palace Square, from V.S. Sadovnikov, Panorama of Nevskii Prospect (1830-35). (C) State Russian Museum, St Petersburg, all rights reserved.

2. Formann and Elers, from V. S. Sadovnikov, Panorama of Nevskii Prospect (1830-35). (C) State Russian Museum, St Petersburg, all rights reserved.

3. Jean Fouquet, Boccace écrivant le De Casibus (1458). Bayerische Staatsbibliothek München (Cod. Gall. 6, fol. 10). Image in the public domain. Wikimedia, https://commons.wikimedia.org/ wiki/File:De_Casibus.jpg

4. A bootmaker's stall, from Adam Olearius's Vermehrte Newe Beschreibung Der Muscowitischen ond Persischen Reyse, So durch gelegenheit einer Holsteinischen Gesandschafft an den Russischen Zaar vnd König in Persien geschehen (1656). Image in the public domain. Wikimedia, https://commons.wikimedia.org/wiki/File:Olearius_ russian_coins.gif

5. Sign of the Bakers' Guild, East Frisian Island of Juist (Lower Saxony, Germany). Image (C) 4028mdk09, CC BY-SA 3.0. Wikimedia, https://commons.wikimedia.org/wiki/File:Symbol_ des_Bäckerhandwerks.JPG

6. A bakers' sign, from V. S. Sadovnikov, Panorama of Nevskii Prospect (1830-35). (C) State Russian Museum, St Petersburg, all rights reserved.

7. Cakes, Mathematical Instruments, and Wigs, from V. S. Sadovnikov, Panorama of Nevskii Prospect (1830-35). (C) State Russian Museum, St Petersburg, all rights reserved.

8. Coats, Frocks, and Musical Instruments, from V. S. Sadovnikov, Panorama of Nevskii Prospect (1830-35). (C) State Russian Museum, St Petersburg, all rights reserved.

9. Rode's shop, from V. S. Sadovnikov, Panorama of Nevskii Prospect (1830-35). (C) State Russian Museum, St Petersburg, all rights reserved.

10. Wolf and Béranger, from V. S. Sadovnikov, Panorama of Nevskii 376

378

380

380

381

382

383

384

387

Prospect (1830-35). (C) State Russian Museum, St Petersburg, all 388 rights reserved. 
11. Smirdin's The Library for Reading, from V. S. Sadovnikov, Panorama of Nevskii Prospect (1830-35). (C) State Russian Museum, St Petersburg, all rights reserved.

12. Bellizard's bookshop, from V. S. Sadovnikov, Panorama of Nevskii Prospect (1830-35). (C) State Russian Museum, St Petersburg, all rights reserved.

13. M. I. Makhaev, View of Elizaveta Petrovna's Summer Palace (1756). From the collection of the State Hermitage Museum, St Petersburg. Image in the public domain. Wikimedia, https://commons. wikimedia.org/wiki/File:Summer_Palace_St_Petersburg.jpeg

14. Gostinyi dvor, from V.S. Sadovnikov, Panorama of Nevskii Prospect (1830-35). (C) State Russian Museum, St Petersburg, all rights reserved.

15. V. S. Sadovnikov, View of the Passazh (1848). Image in the public domain. Wikimedia, https://commons.wikimedia.org/wiki/File: Passazh_department_store_(Sadovnikov).jpg

16. Pavel Semechkin, Interior of the Passazh in St Petersburg (1850s). Image in the public domain. Wikimedia, https://en.wikipedia.org/ wiki/File:Semechkin.jpg

17. Madame La Tour's Panorama and the Optical Telegraph, from V. S. Sadovnikov, Panorama of Nevskii Prospect (1830-35). (C) State Russian Museum, St Petersburg, all rights reserved. 


\section{Information and Empire}

Mechanisms of Communication in Russia, 1600-1850

\section{Edited by Simon Franklin and Katherine Bowers}

From the mid-sixteenth to the mid-nineteenth century Russia was transformed from a moderate-sized, land-locked principality into the largest empire on earth. How did systems of information and communication shape and reflect this extraordinary change?

Information and Empire brings together a range of essays to address this complex question. It examines communication networks such as the postal service and the circulation of news, as well as the growth of a bureaucratic apparatus that informed the government about its people. It also considers the inscription of space from the point of view of mapping and the changing public 'graphosphere' of signs and monuments. More than a series of institutional histories, this book is concerned with the way Russia discovered itself, envisioned itself and represented itself to its people.

Innovative and scholarly, this collection breaks new ground in its approach to communication and information as a field of study in Russia. More broadly, it is an accessible contribution to pre-modern information studies, taking as its basis a country whose history often serves to challenge habitual Western models of development. It is important reading not only for specialists in Russian Studies, but also for students and anyone interested in the history of information and communications.

As with all Open Book publications, this entire book is available to read for free on the publisher's website. Printed and digital editions, together with supplementary digital material, can also be found at www.openbookpublishers.com

Cover image: Clement Cruttwell, Map of the Russian Empire, in Atlas to Cruttwell's Gazetteer, 1799 (top). Image from the first Italian edition of Sigismund von Herberstein's description of Muscovy (Venice, 1550), private collection (bottom).

Cover design by Katherine Bowers and Corin Throsby.

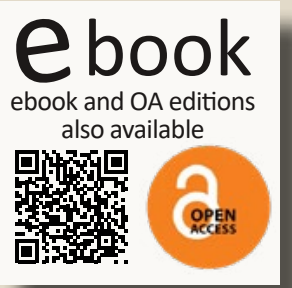

\section{OpenBook Publishers}

